\title{
Water use by short rotation Eucalyptus woodlots in southern Rwanda
}

\author{
C. P. Mugunga $\cdot$ D. Kool $\cdot$ M. T. Van Wijk • \\ G. M. J. Mohren • K. E. Giller
}

Received: 21 August 2014/Accepted: 19 August 2015/Published online: 1 September 2015

(C) The Author(s) 2015. This article is published with open access at Springerlink.com

\begin{abstract}
Eucalyptus is abundant in Rwanda, mainly planted in short rotation woodlots, scattered in small clusters over the hilly landscape. A study was done in Butare and Busoro catchments, southern Rwanda from May to November 2007 to estimated water use of eucalypts in representative catchments in Rwanda, establishing a monthly water balance. We compared eucalypt water use to water use of other key crops in the study area and to that of eucalypts elsewhere. The woodlots had small coppice shoots ranging from 2 to $36 \mathrm{~cm}$ breast height diameter and potential tree transpiration recorded was $3 \mathrm{~mm} \mathrm{~d}^{-1}$. The annual potential tree transpiration was $10 \%$ below annual precipitation. Dry month water deficit observed could be covered by reductions in leaf area, stomatal closure and changes in soil water storage. A sensitivity analysis showed that $50 \%$ leaf area reduction
\end{abstract}

C. P. Mugunga ( $\varangle)$

Department of Forestry and Nature Conservation, College of Agriculture, University of Rwanda, Huye Campus, P. O. Box 56, Butare, Rwanda

e-mail: mugungacp@gmail.com; cpmugunga@ur.ac.rw; canisius.mugunga@wur.nl

D. Kool · K. E. Giller

Plant Production Systems, Wageningen University, P.O. Box 430, 6700 AK Wageningen, The Netherlands e-mail: diliakool@gmail.com

K. E. Giller

e-mail: ken.giller@wur.nl corresponded to potential tree transpiration decline of $32.8 \mathrm{~mm}$. The deficit may not impact tree growth negatively since dry seasons are usually not active for tree growth. The moderate eucalypt water use rate observed in this study may be a function of trees' small size and low tree stocking since such woodlots had less potential transpiration. The observed eucalypt water use rate is smaller than the range reported for eucalypts in Africa and was also smaller than that of key annual crops in the study area. Managing woodlots as short rotations and increasing initial tree spacing may contribute to resolving issues related to catchment hydrology associated with eucalypt plantations.

Keywords Leaf area index $\cdot$ Potential tree transpiration - Catchment water balance - Busoro catchment $\cdot$ Butare catchment

\footnotetext{
M. T. Van Wijk

International Livestock Research Institute (ILRI),

Livestock Systems and the Environment, P.O. Box 30709, Nairobi 00100, Kenya

e-mail:m.vanwijk@cgiar.org

G. M. J. Mohren

Forest Ecology and Forest Management Group, Wageningen University, P.O. Box 47, 6700 AA Wageningen, The Netherlands e-mail: frits.mohren@wur.nl
} 


\section{Introduction}

The genus Eucalyptus (Myrtaceae) comprises more than 700 species and an unknown number of hybrids and varieties (Boland et al. 2006). Only a few of these have potential in industrial plantations (FAO 2000). Eucalyptus species occur naturally in Australia and in the Philippines, Papua New Guinea, Indonesia and Timor. They grow in diverse ecological conditions with some hardy species growing in semi-arid areas, while others are able to grow on marshy and swampy sites. Owing to their wide ecological adaptation, Eucalyptus species are among the most widely cultivated forest trees in the world. In the late 1990s, Eucalyptus plantations were estimated to cover at least 12 million ha throughout the tropical zone, $90 \%$ of which had been established since 1955 (Turnbull 1999). There are now $>20$ million hectares of Eucalyptus plantations around the world and interestingly, more than $50 \%$ of these plantations occur only in three countries: Brazil (4.2 M ha), India (3.9 M ha) and China (2.6 M ha) (Iglesias-Trabado and Wilstermann 2008).

In Africa, there is little quantitative information on the planting of Eucalyptus. Several Eucalyptus species were introduced to the continent in the second half of the nineteenth century. South Africa has the largest area under Eucalyptus plantations of about half a million hectares (Turnbull 1999). Their first planting included introductions to botanical gardens and private arboreta and once in cultivation, their potential was recognized and they were taken to many parts of the world and planted for ornamental value, windbreaks, land reclamation, and oil production (Turnbull 1999). In South Africa, commercial plantations were intensified from 1930 onwards, to meet the demand for wood destined for underground mining.

Eucalyptus species were introduced to the eastern Africa region at about the same time as in South Africa (Dessie and Erkossa 2011). More specifically, plantation forests were established in the early 1900s in Rwanda (Nduwamungu 2011) and most recently in Uganda, since the earliest report was in Kigezi District in 1940 (Kaboggoza 2011). Large scale establishment of industrial plantations in the region began during the period 1911-1960, motivated by the realisation that the slow growing and uneasily propagated indigenous forests would not meet future wood and non-wood forest products (Chamshama 2011). The introduction of the Eucalyptus to East Africa was aimed to meet this demand (Nduwamungu et al. 2008).

As the first step to prepare for plantation forestry expansion in Rwanda a 200 ha Arboretum was established in Ruhande, Butare (southern province) in which exotic tree species were tested, among which 63 eucalypt species were introduced (Burren 1996). Plantations in the region expanded over time, and by the early 1970s the area of Eucalyptus in Ethiopia, Rwanda, Uganda, Kenya and Sudan had reached 95,684 ha (FAO 1979). The largest plantations at that time were in Ethiopia and Rwanda, at 42,300 and 23,000 ha, respectively (Dessie and Erkossa 2011).

Plantation trees and Eucalyptus spp. in particular have provoked controversy regarding their effects on the environment. Some authors support Eucalyptus planting for their economic, social and environmental benefits (Ferraz et al. 2013). On the other hand, Eucalyptus are said to mine large amounts of nutrients, rendering the soils poor and unfit for other use (Lemenih 2004). Plantation trees are reported to take up much water, drying up sites or interfering with water supply for other land uses (Jobbágy et al. 2012). Eucalyptus trees are reported to use water in excess of supply from rainfall (Dye and Versfeld 2007), thereby lowering water tables due to water extraction (Dye 2013). They also reduce water availability for irrigation due to soil hydrophobicity (water repellence) of their litter and their deep and dense root network (Lane et al. 2004). Replacement of natural vegetation by the exotic eucalypts reduces biodiversity (Brockerhoff et al. 2013) and is said to prevent understorey vegetation growth by exhausting soil water and nutrient resources, which also may affect biodiversity negatively (Bouvet 1998). These factors, especially the impacts on water relations, raise considerable concern regarding the long-term sustainability of eucalypt plantations.

In Rwanda, as in many high population density areas in the highlands of eastern Africa, most forest plantations are privately-owned small woodlots. Principal owners include individual farmers and businessmen, and institutions like churches, schools, cooperatives and tea plantation companies (Nduwamungu 2011). This ownership pattern renders much of the landscape of Rwanda to be covered predominantly by trees in small groups, rows or single trees scattered on farms. Forest plantations are dominated by Eucalyptus species which comprise $78 \%$ of all plantations, 
mostly managed as short rotation coppice (Nduwamungu 2011). Woodlots cover about $51 \%$ of plantation forests and are also dominated by Eucalyptus spp. followed by Grevillea robusta and Pinus spp. (Nduwamungu et al. 2008). According to Nduwamungu (2011), preliminary results of surveys carried out by FAO in 2010 to determine the extent of tree resources outside forests (including woodlots below 0.5 ha) show that these resources cover about $6.6 \%$ of total country land area.

Recent policy briefs in Rwanda recommend that the species should be uprooted from wetlands and wherever they grow near water bodies, and their use prohibited in further reforestation (Gahigana 2006). Unfortunately, information on water use by Eucalyptus in Africa is very scanty and particularly lacking in eastern Africa (Bayabil et al. 2010). In Africa, water use by Eucalyptus has only been studied extensively in South Africa, in the Congo, and to a lesser extent in Ethiopia, regions with a clearly different agro-ecological environment from the East African highlands.

To quantify water use by Eucalyptus trees in the East African highlands we estimated the transpiration of the species in the locally dominant management practice, i.e., small woodlots scattered over the landscape by using a leaf area index (LAI)-diameter at breast height $(\mathrm{DBH})$ relationship. On the basis of the derived relationship, we quantified the water use by short rotation Eucalyptus woodlots in representative catchments in southern Rwanda. A monthly water balance of such woodlots was estimated and the overall water use by Eucalyptus trees was compared with other key crops in the study area and to that of Eucalyptus growing in other regions of the world.

\section{Materials and methods}

Study site

The water use by Eucalyptus woodlots was estimated in two catchments in southern Rwanda by employing a LAI-DBH relationship. The woodlots in Busoro catchment were planted by farmers for fuelwood production in the first place but also for soil protection against erosion. Those in Butare catchment were planted by the local government primarily for protection purposes. The catchments were chosen because of the availability of clear Google Earth images, the general representativeness of land use, and the clear demarcation of the boundaries of both catchments. One of the catchments borders the town of Butare, and is referred to as the "Butare catchment". It is located at $2.61^{\circ} \mathrm{S}, 29.72^{\circ} \mathrm{E}$ and covers an area of $472 \mathrm{ha}$. The other catchment is situated to the south near the village of Busoro, and is referred to as the "Busoro catchment" (Fig. 1). This catchment covers an area of 618 ha and is located at $2.67^{\circ} \mathrm{S}, 29.70^{\circ} \mathrm{E}$.

The landscape of the study area is hilly with the villages mostly located on top of the ridges. The predominant land use in both catchments is smallscale agriculture, with short rotation Eucalyptus stands for firewood and timber production as well as prevention of soil erosion. The woodlots were primarily planted by farmers. Based on the agro-ecological classification of Delepièrre (1982) and the elevational classification of Ndayambaje et al. (2012), the catchments are located in the central plateau and hills zone of Rwanda. The climate is sub-humid with moderately high rainfall of $1200 \mathrm{~mm}$ year $^{-1}$ and mean annual temperature of $21{ }^{\circ} \mathrm{C}$. The elevation is around $1700 \mathrm{~m}$ above sea level. The soils are derived from granitic rocks and are classified as oxisols or ultisols (Delepierre 1982).

This study was carried out in 1 year, 2007, and the LAI-DBH relationship was established during the period May-August which is a transition between a wet and dry season, and the woodlot sampling for LAI determination was done in October-November of the same year. This sampling period is during a short rainy season. The difference in the months of field work may not be important since DBH is not expected to change over such a short period. This period starts at the end of the cropping season and at its beginning, most annual crops were being harvested. Most major crops in the upland fields were perennial, including banana, cassava and some sweet potato. In the relatively flat valleys rice was grown. Most households had an avocado tree and a small Eucalyptus plot for domestic wood supply. E. saligna was the predominant species, with a few small stands of E. tereticornis, E. maculata, E. maidenii, E. microcorys, and E. citriodora. Some woodlots were comprised of mixed species of Eucalyptus. Besides Eucalyptus, there were a few small stands of other species. Pinus patula and Grevillea robusta were frequently found scattered on farms, Euphorbia tirucallii was used to mark farm boundaries and Jacaranda mimosifolia and Ficus thonningii were 

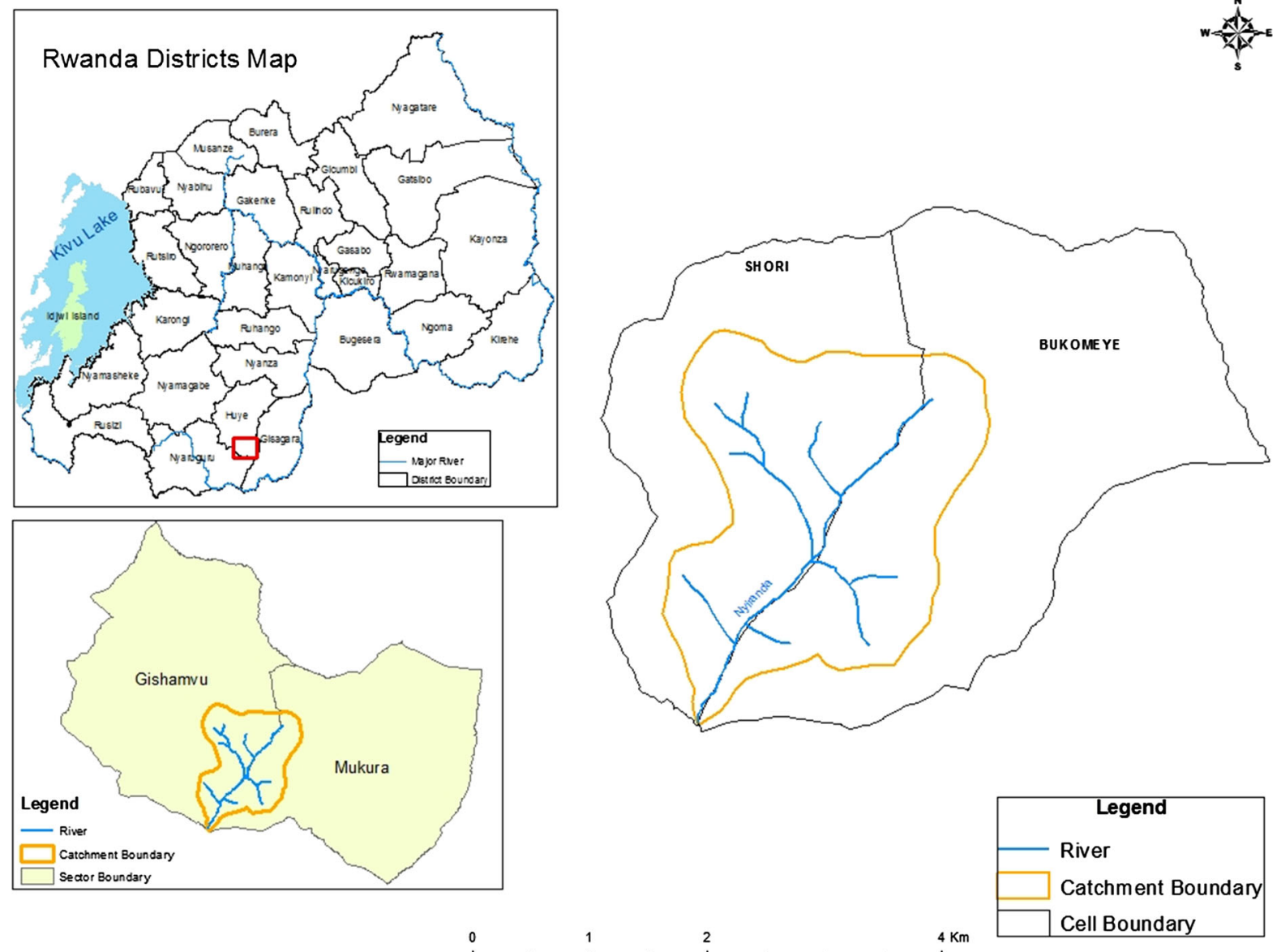

Fig. 1 The map of Rwanda showing Busoro catchment using ArcGIS. The catchment is located in Huye (former Butare) district and is bordered by Shori cell of Gishamvu sector on the west and Bukomeye cell of Mukura sector on the east

grown in home gardens. Eucalyptus woodlots were mostly coppice stands and were located on the steepest parts of the landscape on infertile soils.

Estimation of the water use by Eucalyptus trees

We estimated the water use of Eucalyptus woodlots in the catchments by quantifying the most important components of the water balance. The water balance can be determined by calculating the amounts of water entering, stored and leaving a system. The inputs and outputs of the water balance of the woodlots taken into account are based on Whitehead and Beadle (2004):

$P=E T+\Delta S+D+R$

where $P$ is precipitation, ET is total evapotranspiration, $\Delta S$ is the change in total soil water storage, $D$ is drainage and $R$ is surface run-off, all in $\mathrm{mm} \mathrm{d}^{-1}$.
Subsequently, ET was divided into tree transpiration $\left(E_{t}\right)$, evaporation of leaf interception $\left(E_{i}\right)$, and evaporation from understorey and the soil surface $\left(E_{u}\right.$, Whitehead and Beadle 2004). Precipitation ( $\mathrm{mm} \mathrm{d}^{-1}$ ) was derived from daily climate data from the weather stations of Butare and Nyakibanda. These were used to quantify a monthly water balance, thereby capturing the variations in the water balance throughout the year. Generally, $E_{u}$ is estimated at $10 \%$ or less of $E_{t}$ (Whitehead and Beadle 2004), which is the value we used. $E_{u}$ is known to be directly related to the LAI (Callister and Adams 2006).

$E_{t}$ and $E_{i}$ are considered the major components of evapotranspiration (Whitehead and Beadle 2004). $E_{i}$ can be estimated as a percentage of annual rainfall, and is normally affected by the leaf area and the shape of the leaves of the vegetation, as well as by the rainfall distribution. Interception losses in Eucalyptus 
woodlots are generally less than those from woodlots of other tree species, which can be explained by the relatively small LAI of Eucalyptus trees compared to other tree species (Calder 1986). LAI for E. saligna, one of the most dominant eucalypt species in the study area, was found in a different study in the same area to range from 2.5 to $3.5 \mathrm{~m}^{2} / \mathrm{m}^{-2}$ (Nsabimana et al. 2009). Eucalyptus interception losses were reported to range from $4 \%$ in South Africa to $34 \%$ of the annual rainfall in Australia, India and Israel (Hall et al. 1992; Calder 1986). Most studies report $E_{i}$ to range from 10 to $11 \%$ of annual rainfall (Whitehead and Beadle 2004). In South Africa interception losses were higher for large trees than for small ones. As the woodlots in our study areas are mostly coppice stands of several generations, dominated by very small coppice shoots of small DBH ranging from 2 to $36 \mathrm{~cm}$, a value on the lower side of the range for interception losses seemed most appropriate. We therefore assumed interception losses to be $10 \%$ of annual rainfall.

$E_{t}$ was estimated for individual trees using the model of Radersma et al. (2006). The model describes individual tree transpiration on the basis of an estimation of the leaf area. The model assumes wellwatered conditions, and therefore describes the potential tree transpiration ( $E_{t p}$, Radersma et al. 2006; Whitehead and Beadle 2004). Radersma et al. (2006) used sap-flow measurements to quantify the relationship between leaf area and $E_{t p}$ for Eucalyptus trees in sub-humid Kenya, an area with similar agro-ecological conditions to our study site in Rwanda. The variance in measured transpiration accounted for by leaf area, was compared with the variance accounted for by leaf area together with saturation deficit, radiation, and the direct effect of soil water content. Leaf area was the most important determining factor for transpiration across a large range of leaf. The equation that was established for $E_{t p}$ in relation to leaf area is:

$E_{t p}=c \times L A^{0.63}$

where $E_{t p}$ is in $\mathrm{g} \mathrm{d}^{-1}, c$ is coefficient 1058 $\left(\mathrm{g} \mathrm{d}^{-1} \mathrm{~m}^{-2}\right)$, and $L A$ is leaf area $\left(\mathrm{m}^{2}\right)$. The explained variance for this equation was 0.62 . This equation does not take into account that during the dry season Eucalyptus trees normally shed their leaves and thus the relationship between DBH and leaf area changes across seasons (Roberts et al. 1992). During prolonged dry periods, shedding of leaves is common in Eucalyptus (Ladiges 1974) and this can result in large seasonal changes in LAI, depending on the timing and magnitude of leaf production and shedding (Whitehead and Beadle 2004). As a result, transpiration of Eucalyptus during the dry season could be overestimated. Although this equation was established specifically for $E$. grandis, water-use per unit $L A$ is known not to vary greatly among Eucalyptus species (Radersma et al. 2006; Whitehead and Beadle 2004). Therefore the same equation was applied to all Eucalyptus species. E. saligna dominated in the study area and is morphologically similar to E. grandis (Burren 1996).

The leaf area of individual trees was derived from the leaf biomass, based on the relationship between leaf biomass and DBH. Specific leaf area (SLA) or the ratio of leaf area to leaf mass $\left(\mathrm{m}^{-2} \mathrm{~kg}^{-1}\right)$ or its inverse, leaf mass per area (LMA) are important ecophysiological parameters widely used to derive canopy leaf area from leaf biomass (Diao et al. 2010). The relationship between leaf dry matter and DBH was established for E. saligna by Mugunga et al. (in prep.) as:

$W_{L}=\alpha+\beta_{1} \mathrm{DBH}^{2}$

where $W_{L}$ is leaf biomass $(\mathrm{kg}), \alpha$ is intercept $\left(0.881461 \mathrm{~kg} \mathrm{~cm}^{-2}\right), \quad \beta_{1}$ is model coefficient $\left(0.026311 \mathrm{~kg} \mathrm{~cm}^{-1}\right)$ and DBH in $\mathrm{cm}$. The explained variance of observed $W_{L}$ using this equation was 0.88 . After calculating the $W_{L}$ for each tree, $L A$ was obtained by multiplying the leaf biomass by the $S L A\left(\mathrm{~m}^{2} \mathrm{~kg}^{-1}\right)$. To obtain the values of the $S L A$, a sample of 80 leaves was taken for the test species. Each leaf was measured for projected leaf area and fresh weight, and the corresponding dry weight was calculated by multiplying with a dry weight:green weight conversion factor of 0.3 derived from the study by Mugunga et al. (in prep.). The steps taken to estimate the $E_{t p}$ of individual trees are shown in Fig. 2.

After determining the $E_{t p}$ for the individual trees, the results were aggregated to establish the $E_{t p}$ of Eucalyptus woodlots across the two catchments. Google Earth images of the catchments showed a very patchy landscape, with small fields of grain crops interspersed with banana fields and Eucalyptus woodlots. Some of the Eucalyptus woodlots were dense, although bare soil around the trees was visible in most 


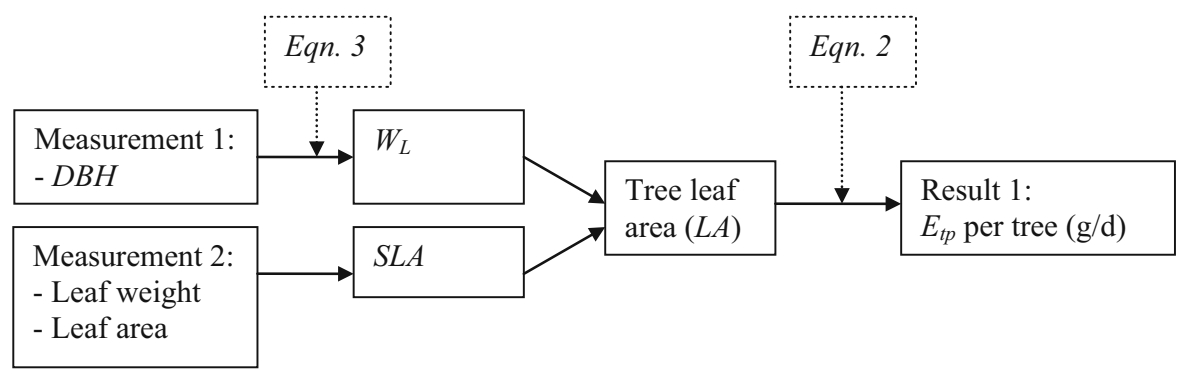

Fig. 2 Determining the leaf area and estimating the potential transpiration $\left(E_{t p}\right)$ for individual trees. $D B H$ is tree diameter at breast height, $W_{L}$ leaf biomass and $S L A$ is specific leaf area

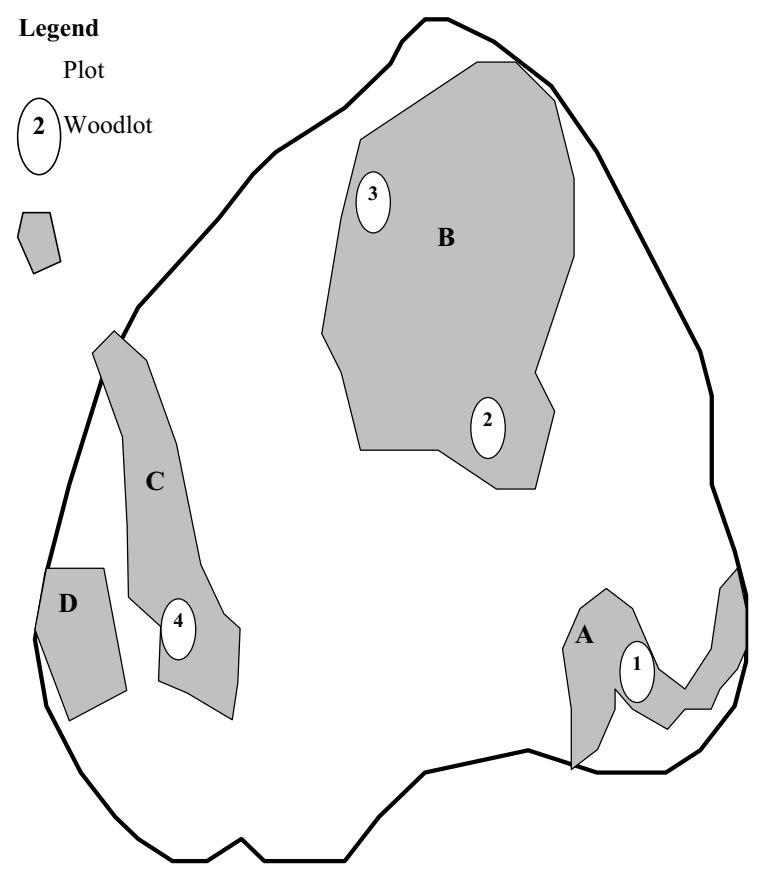

Fig. 3 Sampling strategy: The grey areas represent a number of woodlots in a catchment. In this example, 4 plots were measured. The first plot was taken in woodlot $A$. The calculated total tree potential transpiration $\left(E_{t p}\right)$ for this plot was extrapolated to the entire area of $A$. In woodlot $\mathrm{B}$ two plots were taken, as this was a larger woodlot with more variation. The average $E_{t p}$ of the two plots was used to compute the total $E_{t p}$ of $B$. Woodlot $C$ and $D$ are very similar. Only one plot was taken and $E_{t p}$ extrapolated to represent both areas

of them. Busoro catchment was divided into two parts: the northern and the southern sub-catchments. Sampling was done by taking one or more 0.02 ha $(8 \mathrm{~m}$ radius) plots per woodlot depending on woodlot size (Fig. 3), while some small woodlots with widths smaller than $16 \mathrm{~m}$ were sampled entirely. In each plot, all tree species were identified and measured for DBH.

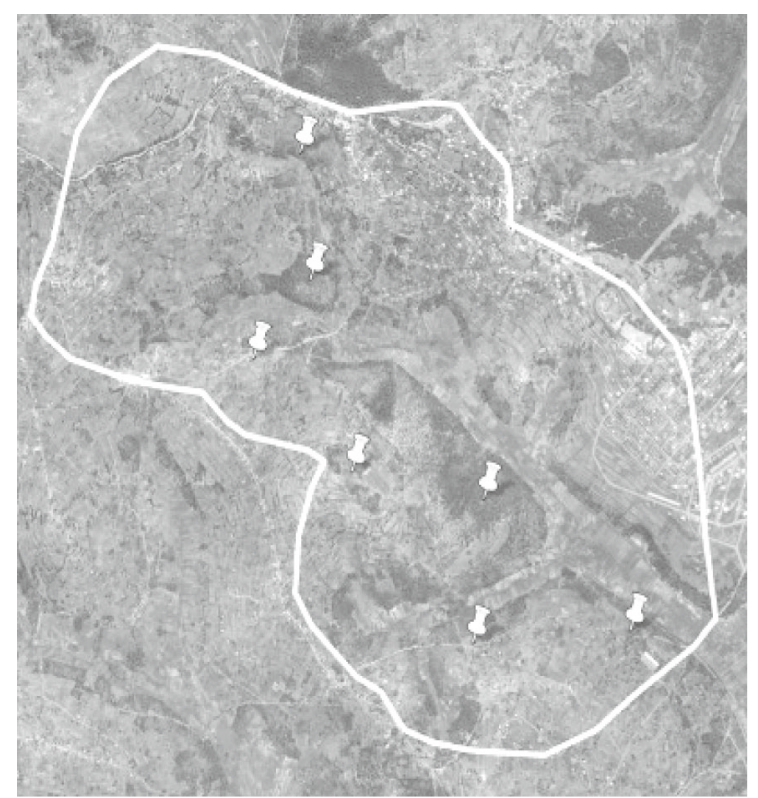

Butare catchment. In this catchment 7 plots were measured.

Fig. 4 Butare catchment. In this catchment 7 plots were measured

A total of 59 samples were taken in the Busoro catchment, representing 15 woodlot areas in the southern sub-catchment and 36 woodlot areas in the northern sub-catchment. Seven samples representing 7 woodlot areas were taken from the Butare catchment (Fig. 4), giving a total of 66 plots representing 58 woodlot areas.

The $E_{t p}$ of each individual tree was calculated using the equation of Radersma et al. (2006). Subsequently the sum of the $E_{t p}$ of all individual trees was divided by the plot area to determine the $E_{t p}$ per $\mathrm{m}^{2}$ for each plot. Areas of the woodlots were determined using the 
Google Earth images. The total $E_{t p}$ of Eucalyptus woodlots at catchment level was calculated by aggregating the $E_{t p}$ of all the individual woodlots and converting them to $\mathrm{mm} \mathrm{d}^{-1}$ (Fig. 5). Catchment water balance was developed for the Busoro catchment by considering $P$ as the sole input and the $E_{t p}, E_{i}$ and $E_{u}$ the outputs.

For data analysis, linear regression was used to explore the correlation between tree DBH and total tree water use. Mean DBH of each plot was plotted against the total water use of each plot to determine if the total water use per unit area was affected by the size of the trees.

It is well known that LAI during the mid- to late-dry seasons is usually $40-50 \%$ smaller than the LAI during the wet- and early-dry seasons in Eucalyptus forests (Nouvellon et al. 2010). Reductions in the LAI were reported to be up to $50 \%$ even in moist tropical forests in Congo-Guinean forest (de Wasseige et al. 2003), in Mexico (Mass et al. 1995) and in Thailand (Tanaka et al. 2003), while leaf shedding during a severe drought in Australia ranged from 50 to $97 \%$ (Pook 1855). For this reason, we wanted to adjust the $E_{t p}$ following LAI reductions in the driest months. Unfortunately, the exact LAI variation in our study area is unknown and we did not find reports on LAI variations for the East-African region. To capture seasonal variations in LAI and the resulting changes in $E_{t p}$, a sensitivity analysis was done by assuming reductions in the amounts of LAI in the driest months of June, July, August and September. To calculate the reductions in $E_{t p}$, Eq. 2 above was applied with an assumption that dry season reductions in $L A$ corresponded to reductions in LAI since the trees covered the same area. We used $L A$ reductions of 15, 30 and $50 \%$ and calculated the related reductions in $E_{t p}$ herein-after referred to as adjusted $E_{t p}\left(\operatorname{Adj} . E_{t p}\right)$. The new (adjusted) $E_{t p}$ values were computed as:

$$
\begin{aligned}
\operatorname{Adj.E_{tp}} & =\left((\mathrm{c} * L A)^{0.63} *\left((1-r)^{0.63}\right)\right) \\
& =E_{t p} . \text { orig } *\left((1-r)^{0.63}\right)
\end{aligned}
$$

where $c$ is a constant described in Eq. 2, $r$ is \% reduction in $L A$ expressed as a fraction (50\% reduction is entered in the equation as 0.5$)$ and $E_{t p}$. orig is the original $E_{t p}\left(\mathrm{~mm}\right.$ month $\left.^{-1}\right)$.

The available water was estimated by assuming that the water accumulated in the root zone during the wetter months was available for evaporation in the drier months. The soil water storage $(\Delta S)$ and physiological regulation on water loss by closing stomata were assumed to further reduce the water deficit during dry months, thereby contributing to the closing of the catchment water balance. Annual difference between potential $E T$ and $P$ were attributed to runoff and drainage.

\section{Results}

Results on the occurrence of tree species, number of stems $\mathrm{ha}^{-1}$, tree DBH and leaf area are summarized in Tables 1 and 2 and Appendix in Table 10 for southern Busoro sub-catchment, Butare catchment and the northern Busoro sub-catchment respectively. Woodlots in the study area were dominated by Eucalyptus species and about 43 and $35 \%$ of all the standing stems per hectare $(\mathrm{N})$ identified were E. tereticornis and $E$. saligna respectively. The number of stems ha ${ }^{-1}$ ranged from 50 to 11,500 , DBH from 2 to $36 \mathrm{~cm}$ and leaf area from 8 to $211 \mathrm{~m}^{2}$. The SLA's for E. saligna and $E$. tereticornis were 12.2 and $16\left(\mathrm{~m}^{2} \mathrm{~kg}^{-1}\right)$ respectively. The total forested area, $E_{t p}$ and relative cover by eucalypt woodlots for Butare catchment, and northern and southern Busoro sub-catchments are presented in Tables 3, 4 and 5 respectively.

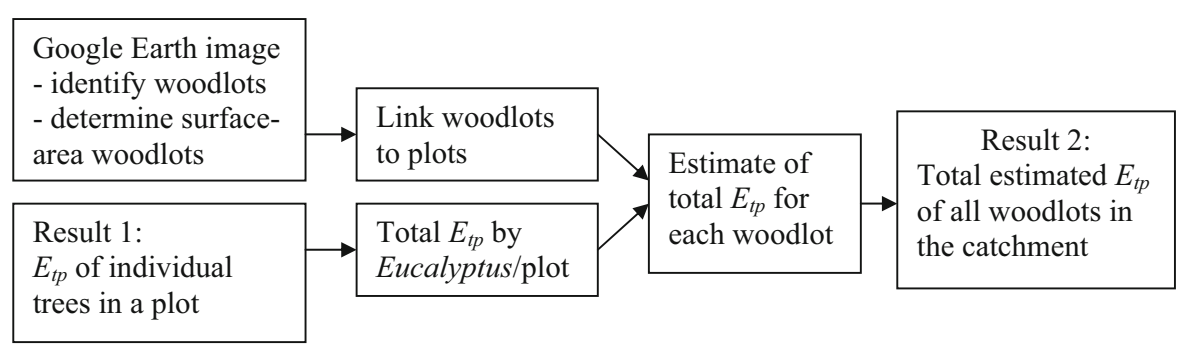

Fig. 5 Procedure for determining potential tree transpiration $\left(E_{t p}\right)$ on catchment level 
Table 1 No. of sample plots/woodlot, tree species, number of stems, tree DBH and leaf area of woodlot trees in Busoro southern sub-catchment, southern Rwanda

\begin{tabular}{|c|c|c|c|c|c|c|c|c|c|c|}
\hline \multirow[t]{2}{*}{ Woodlot no. } & \multirow[t]{2}{*}{ Plot no. } & \multirow[t]{2}{*}{ Species } & \multicolumn{2}{|c|}{ No. of stems } & \multicolumn{3}{|c|}{ Tree DBH $(\mathrm{cm})$} & \multicolumn{3}{|c|}{ Tree leaf area $\left(\mathrm{m}^{2}\right)$} \\
\hline & & & $\left(\mathrm{plot}^{-1}\right)$ & $\left(\mathrm{ha}^{-1}\right)$ & Min & $\operatorname{Max}$ & $\mathrm{Av} \pm \mathrm{Std}$ & Min & $\operatorname{Max}$ & $\mathrm{Av} \pm \mathrm{Std}$ \\
\hline \multirow[t]{4}{*}{ SB-1* } & \multirow[t]{4}{*}{$35+37$} & E. saligna & 47 & 1150 & 1 & 8 & $4 \pm 2$ & 6 & 49 & $18 \pm 10$ \\
\hline & & E. teriticornis & 68 & 1700 & 1 & 8 & $3 \pm 2$ & 5 & 34 & $11 \pm 7$ \\
\hline & & E. microcorys & 18 & 450 & 2 & 5 & $3 \pm 1$ & 7 & 24 & $13 \pm 5$ \\
\hline & & Other & 1 & $<50$ & 20 & 20 & 20 & 176 & 176 & 176 \\
\hline \multirow[t]{2}{*}{ SB-2 } & \multirow[t]{2}{*}{47} & E. saligna & 34 & 1700 & 3 & 20 & $12 \pm 4$ & 4 & 12 & $96 \pm 43$ \\
\hline & & E. microcorys & 1 & 50 & 11 & 11 & 11 & 72 & 72 & 72 \\
\hline \multirow[t]{2}{*}{ SB-3 } & \multirow[t]{2}{*}{48} & E. saligna & 56 & 2800 & 1 & 26 & $9 \pm 6$ & 6 & 306 & $71 \pm 65$ \\
\hline & & E.tereticornis & 6 & 300 & 2 & 15 & $10 \pm 5$ & 7 & 99 & $56 \pm 36$ \\
\hline \multirow[t]{4}{*}{ SB-4 } & \multirow[t]{4}{*}{49} & E. saligna & 19 & 950 & 1 & 20 & $5 \pm 6$ & 6 & 212 & $38 \pm 56$ \\
\hline & & E. tereticornis & 2 & 100 & 4 & 5 & $5 \pm 1$ & 16 & 21 & $18 \pm 3$ \\
\hline & & E. microcorys & 100 & 4950 & 1 & 23 & $6 \pm 5$ & 6 & 213 & $39 \pm 43$ \\
\hline & & Other & 1 & 50 & 14 & 14 & 14 & 103 & 103 & 103 \\
\hline \multirow[t]{4}{*}{ SB-5 } & \multirow[t]{4}{*}{50} & E. tereticornis & 106 & 5250 & 1 & 13 & $4 \pm 3$ & 5 & 77 & $18 \pm 15$ \\
\hline & & E. microcorys & 5 & 250 & 6 & 9 & $8 \pm 1$ & 27 & 51 & $46 \pm 10$ \\
\hline & & E. saligna & 5 & 250 & 2 & 9 & $4 \pm 3$ & 8 & 54 & $20 \pm 19$ \\
\hline & & E. tereticornis & 13 & 650 & 1 & 4 & $2 \pm 1$ & 5 & 16 & $8 \pm 4$ \\
\hline SB-6 & 51 & E. microcorys & 74 & 3700 & 1 & 20 & $6 \pm 4$ & 6 & 174 & $33 \pm 35$ \\
\hline SB-7 & 52 & Other & 1 & 50 & 14 & 14 & 14 & 100 & 100 & 100 \\
\hline \multirow[t]{2}{*}{ SB-8 } & \multirow[t]{2}{*}{53} & E. saligna & 23 & 1150 & 1 & 16 & $8 \pm 5$ & 6 & 146 & $58 \pm 43$ \\
\hline & & E. tereticornis & 45 & 2250 & 2 & 17 & $6 \pm 4$ & 6 & 119 & $29 \pm 24$ \\
\hline \multirow[t]{2}{*}{ SB-9 } & \multirow[t]{2}{*}{54} & E. saligna & 20 & 1000 & 2 & 19 & $10 \pm 5$ & 11 & 192 & $76 \pm 54$ \\
\hline & & E. Microcorys & 71 & 3550 & 1 & 20 & $8 \pm 5$ & 6 & 178 & $52 \pm 47$ \\
\hline \multirow[t]{2}{*}{ SB-10 } & \multirow[t]{2}{*}{55} & E. saligna & 5 & 250 & 6 & 17 & $11 \pm 4$ & 30 & 161 & $87 \pm 47$ \\
\hline & & E. tereticornis & 83 & 4150 & 1 & 13 & $5 \pm 3$ & 5 & 80 & $21 \pm 17$ \\
\hline SB-11 & 56 & E. saligna & 68 & 3400 & 2 & 24 & $7 \pm 6$ & 8 & 275 & $54 \pm 65$ \\
\hline \multirow[t]{5}{*}{ SB-12 } & \multirow[t]{5}{*}{57} & E. microcorys & 15 & 750 & 5 & 19 & $11 \pm 4$ & 19 & 156 & $73 \pm 37$ \\
\hline & & E. tereticornis & 221 & 11,000 & 1 & 8 & $2 \pm 1$ & 5 & 34 & $9 \pm 4$ \\
\hline & & E. saligna & 84 & 4200 & 1 & 21 & $8 \pm 5$ & 6 & 229 & $62 \pm 54$ \\
\hline & & E. microcorys & 6 & 300 & 2 & 13 & $8 \pm 4$ & 7 & 84 & $45 \pm 31$ \\
\hline & & Other & 11 & 550 & 1 & 27 & $8 \pm 9$ & 6 & 287 & $64 \pm 95$ \\
\hline SB-13 & 58 & E. saligna & 141 & 7000 & 2 & 8 & $3 \pm 1$ & 10 & 45 & $16 \pm 8$ \\
\hline SB-14 & 59 & E. tereticornis & 90 & 4500 & 2 & 6 & $3 \pm 2$ & 6 & 26 & $12 \pm 7$ \\
\hline \multirow[t]{2}{*}{ SB-15 } & \multirow[t]{2}{*}{$58-59$} & E. saligna & 141 & 3500 & 2 & 8 & $3 \pm 1$ & 10 & 45 & $16 \pm 8$ \\
\hline & & E. tereticornis & 90 & 2250 & 2 & 6 & $3 \pm 2$ & 6 & 26 & $12 \pm 7$ \\
\hline
\end{tabular}

* Southern Busoro sub-catchment

In northern Busoro, the sampled woodlots were relatively small with areas ranging from 130 to $8000 \mathrm{~m}^{2}$, and four larger woodlots with areas of $14,300-41,700 \mathrm{~m}^{2}$ (Table 3). There was a wide range in $E_{t p}$, with $4.58 \mathrm{~mm} \mathrm{~d}^{-1}$ for Plot 38 and only $0.41 \mathrm{~mm} \mathrm{~d}^{-1}$ for Plot 17. This can be explained by the size and number of trees in the respective plots. Plot 17 was a thinly spread coppice stand with a mean DBH of 4-6 cm while Plot 38 represented an area with full grown trees with a mean DBH of 10-36 cm. In the southern Busoro sub-catchment the samples represented areas ranging from 3000 to $62,000 \mathrm{~m}^{2}$, and one 
Table 2 No. of sample plots/woodlot, tree species, number of trees, tree DBH and leaf area of woodlot trees in Butare catchment, southern Rwanda

\begin{tabular}{|c|c|c|c|c|c|c|c|c|c|c|}
\hline \multirow[t]{2}{*}{ Woodlot no. } & \multirow[t]{2}{*}{ Plot no. } & \multirow[t]{2}{*}{ Species } & \multicolumn{2}{|c|}{ No. of stems } & \multicolumn{3}{|c|}{ Tree DBH $(\mathrm{cm})$} & \multicolumn{3}{|c|}{ Tree leaf area $\left(\mathrm{m}^{2}\right)$} \\
\hline & & & $\left(\right.$ plot $\left.^{-1}\right)$ & $\left(\mathrm{ha}^{-1}\right)$ & Min & $\operatorname{Max}$ & $\mathrm{Av} \pm \mathrm{Std}$ & Min & $\operatorname{Max}$ & $\mathrm{Av} \pm \mathrm{Std}$ \\
\hline Bt-1* & 1 & E. saligna & 145 & 7200 & 1 & 9 & $2 \pm 1$ & 5 & 47 & $8 \pm 5$ \\
\hline \multirow[t]{4}{*}{ Bt-2 } & 2 & E. saligna & 14 & 700 & 1 & 5 & $2 \pm 1$ & 8 & 28 & $12 \pm 5$ \\
\hline & & E. tereticornis & 110 & 5450 & 1 & 7 & $3 \pm 1$ & 5 & 27 & $10 \pm 4$ \\
\hline & & E. microcorys & 10 & 500 & 2 & 6 & $4 \pm 1$ & 1 & 3 & $1 \pm 1$ \\
\hline & & Other & 1 & 50 & 1 & 2 & $1 \pm 0$ & 1 & 1 & $1 \pm 0$ \\
\hline \multirow[t]{3}{*}{ Bt-3 } & 3 & E. saligna & 22 & 1100 & 1 & 14 & $3 \pm 3$ & 6 & 119 & $16 \pm 23$ \\
\hline & & E. tereticornis & 33 & 1650 & 1 & 8 & $3 \pm 2$ & 5 & 37 & $10 \pm 7$ \\
\hline & & E. microcorys & 1 & 50 & 11 & 11 & $11 \pm 0$ & 7 & 7 & $7 \pm 0$ \\
\hline \multirow[t]{4}{*}{ Bt-4 } & 4 & E. saligna & 20 & 1000 & 3 & 28 & $8 \pm 8$ & 12 & 353 & $66 \pm 95$ \\
\hline & & E. tereticornis & 3 & 150 & 3 & 10 & $10 \pm 4$ & 9 & 50 & $27 \pm 21$ \\
\hline & & E. maculata & 37 & 1850 & 2 & 23 & $8 \pm 7$ & 1 & 23 & $5 \pm 6$ \\
\hline & & Other & 3 & 150 & 3 & 18 & $9 \pm 8$ & 1 & 15 & $6 \pm 7$ \\
\hline \multirow[t]{3}{*}{ Bt-5 } & 5 & E. saligna & 19 & 950 & 1 & 4 & $2 \pm 1$ & 6 & 16 & $10 \pm 3$ \\
\hline & & E. tereticornis & 6 & 300 & 1 & 1 & $1 \pm 1$ & 5 & 5 & $5 \pm 0$ \\
\hline & & E. citriodora & 80 & 4000 & 1 & 4 & $3 \pm 5$ & 6 & 308 & $18 \pm 54$ \\
\hline \multirow[t]{6}{*}{ Bt-6 } & 6 & E. saligna & 4 & 200 & 2 & 3 & $2 \pm 0$ & 9 & 13 & $11 \pm 2$ \\
\hline & & E. tereticornis & 17 & 850 & 1 & 5 & $2 \pm 1$ & 5 & 19 & $8 \pm 4$ \\
\hline & & E. microcorys & 5 & 250 & 2 & 7 & $5 \pm 3$ & 7 & 33 & $22 \pm 14$ \\
\hline & & E. citriodora & 61 & 3050 & 1 & 14 & $5 \pm 4$ & 1 & 101 & $25 \pm 25$ \\
\hline & & E. maidenii & 18 & 900 & 1 & 14 & $4 \pm 3$ & 6 & 97 & $18 \pm 21$ \\
\hline & & Other & 4 & 200 & 1 & 2 & $1 \pm 0$ & 6 & 8 & $7 \pm 1$ \\
\hline \multirow[t]{2}{*}{ Bt-7 } & 7 & E. saligna & 10 & 500 & 2 & 6 & $4 \pm 2$ & 10 & 34 & $21 \pm 9$ \\
\hline & & E. tereticornis & 62 & 3100 & 1 & 25 & $7 \pm 7$ & 5 & 215 & $45 \pm 5.3$ \\
\hline
\end{tabular}

* Butare catchment

area of $154,000 \mathrm{~m}^{2}$ (Table 4). The highest $E_{t p}$ was found in Plot 57, with a value of $6.44 \mathrm{~mm} \mathrm{~d}^{-1}$. This plot was located in a very dense E. saligna and $E$. microcorys stand, with an average DBH of $8 \mathrm{~cm}$. $E$. microcorys stands were in general more leafy, denser and darker than woodlots with other species. This value may be over-estimated since the water use: leaf area relation of Radersma et al. (2006) is based on the assumption that there is little or no light competition between trees. Linear regression of tree DBH and total tree water use showed no correlation between these two variables, indicating that an increase in mean DBH was compensated for by a decrease in the number of trees per plot (data not shown). For Butare catchment (Table 5) the areas covered by a plot range from 50,000 to $172,000 \mathrm{~m}^{2}$. There was less variation than in the Butare catchment because the plots here represented large areas. Actually the woodlots in this catchment belong to the local government and not to the smallholder farmers. Interestingly the total $E_{t p}$ of the Butare catchment was similar to that of the Busoro catchment, that likely management differences between the different types of owners in the two study areas did not have a major impact on the total water use. The $E_{t p}$ here ranges from 1.34 to $3.44 \mathrm{~mm} \mathrm{~d}^{-1}$. The percentage of the area covered by trees in the three sub-catchments ranged from 10.9 to $17.4 \%$ of the total catchment. Table 6 gives a summary of the weighted average estimates of $E_{t p}$ for Eucalyptus woodlots in the whole study area.

Precipitation of the study site recorded at Butare and Nyakibanda meteorological (southern Rwanda) stations from 1971 to 1992 gave a monthly averages ranging from $8 \mathrm{~mm}$ in July to $219 \mathrm{~mm}$ in April 
Table 3 No. of sample plots/woodlot, woodlot area, estimates of potential tree transpiration $\left(E_{\mathrm{tp}}\right)$ and extent of cover by Eucalyptus woodlots in northern Busoro subcatchment
* Northern Busoro subcatchment

\begin{tabular}{|c|c|c|c|c|c|c|}
\hline \multirow[t]{2}{*}{ Woodlot no. } & \multirow[t]{2}{*}{ Plot no. } & \multirow{2}{*}{$\begin{array}{l}\text { Woodlot area } \\
\left(\mathrm{m}^{2}\right)\end{array}$} & \multicolumn{3}{|c|}{ Potential tree transpiration $\left(E_{t p}\right)$} & \multirow{2}{*}{$\begin{array}{l}\text { Cover } \\
(\%)\end{array}$} \\
\hline & & & $\left(\mathrm{g} \mathrm{d}^{-1}\right)$ & $\left(\mathrm{g} \mathrm{d}^{-1} \mathrm{~m}^{2}\right)$ & $\left(\mathrm{mm} \mathrm{d}^{-1}\right)$ & \\
\hline NB-1* & 1 & 1800 & $2.11 \mathrm{E}+06$ & 1173 & 1.17 & 100 \\
\hline NB-2 & 2 & 3400 & $4.39 \mathrm{E}+06$ & 1291 & 1.29 & 100 \\
\hline NB-3 & 3 & 540 & $5.32 \mathrm{E}+05$ & 984 & 0.98 & 100 \\
\hline NB-4 & 4 & 2100 & $1.45 \mathrm{E}+06$ & 692 & 0.69 & 98 \\
\hline NB-5 & 5 & 530 & $1.46 \mathrm{E}+06$ & 2761 & 2.76 & 100 \\
\hline NB-6 & 6 & 710 & $1.24 \mathrm{E}+06$ & 1745 & 1.74 & 98 \\
\hline NB-7 & 7 & 440 & $3.10 \mathrm{E}+05$ & 704 & 0.7 & 100 \\
\hline NB-8 & 8 & 1500 & $1.01 \mathrm{E}+06$ & 671 & 0.67 & 34 \\
\hline NB-9 & 9 & 1600 & $2.26 \mathrm{E}+06$ & 1411 & 1.41 & 38 \\
\hline NB-10 & 10 & 760 & $1.37 \mathrm{E}+06$ & 1801 & 1.8 & 0 \\
\hline NB-11 & 11 & 330 & $2.55 \mathrm{E}+05$ & 774 & 0.77 & 100 \\
\hline NB-12 & 12 & 3680 & $3.49 \mathrm{E}+06$ & 949 & 0.95 & 100 \\
\hline NB-13 & $13-40$ & 2700 & $4.69 \mathrm{E}+06$ & 1738 & 1.74 & 92 \\
\hline NB-14 & 15 & 500 & $2.65 \mathrm{E}+05$ & 530 & 0.53 & 100 \\
\hline NB-15 & 16 & 600 & $1.46 \mathrm{E}+06$ & 2437 & 2.44 & 100 \\
\hline NB-16 & 17 & 500 & $2.07 \mathrm{E}+05$ & 415 & 0.41 & 94 \\
\hline NB-17 & 18 & 130 & $1.52 \mathrm{E}+05$ & 1166 & 1.17 & 100 \\
\hline NB-18 & $19-20$ & 4000 & $5.95 \mathrm{E}+06$ & 1488 & 1.49 & 100 \\
\hline NB-19 & $21-22$ & 670 & $6.38 \mathrm{E}+05$ & 953 & 0.95 & 100 \\
\hline NB-20 & $23-24$ & 2000 & $3.86 \mathrm{E}+06$ & 1932 & 1.93 & 100 \\
\hline NB-21 & 25 & 1800 & $2.15 \mathrm{E}+06$ & 1195 & 1.19 & 100 \\
\hline NB-22 & $26-27$ & 14,300 & $5.54 \mathrm{E}+07$ & 3874 & 3.87 & 100 \\
\hline NB-23 & $28-29$ & 3700 & $6.66 \mathrm{E}+06$ & 1799 & 1.8 & 100 \\
\hline NB-24 & 30 & 7800 & $1.23 \mathrm{E}+07$ & 1580 & 1.58 & 100 \\
\hline NB-25 & $31-36$ & 31,400 & $5.51 \mathrm{E}+07$ & 1754 & 1.75 & 97 \\
\hline NB-26 & $35+37$ & 20,000 & $3.69 \mathrm{E}+07$ & 1847 & 1.85 & 97 \\
\hline NB-27 & 38 & 6800 & $3.11 \mathrm{E}+07$ & 4575 & 4.58 & 88 \\
\hline NB-28 & 39 & 4100 & $9.84 \mathrm{E}+06$ & 2399 & 2.4 & 100 \\
\hline NB-29 & 40 & 5600 & $1.28 \mathrm{E}+07$ & 2279 & 2.28 & 74 \\
\hline NB-30 & 41 & 4200 & $1.65 \mathrm{E}+07$ & 3939 & 3.94 & 98 \\
\hline NB-31 & 42 & 1800 & $3.17 \mathrm{E}+06$ & 1760 & 1.76 & 100 \\
\hline NB-32 & 43 & 900 & $2.69 \mathrm{E}+06$ & 2989 & 2.99 & 100 \\
\hline NB-33 & $42-43$ & 41,700 & $9.90 \mathrm{E}+07$ & 2375 & 2.37 & 100 \\
\hline NB-34 & 44 & 7400 & $2.56 \mathrm{E}+07$ & 3464 & 3.46 & 100 \\
\hline NB-35 & 45 & 8000 & $2.45 \mathrm{E}+07$ & 3064 & 3.06 & 89 \\
\hline NB-36 & 46 & 6000 & $5.52 \mathrm{E}+06$ & 920 & 0.92 & 0 \\
\hline Total & & 193,990 & $4.36 \mathrm{E}+08$ & 2250 & 2.25 & 95 \\
\hline \multicolumn{3}{|c|}{ Total area catchment $\left(\mathrm{m}^{2}\right)$} & \multicolumn{4}{|l|}{$1,7850,000$} \\
\hline \multicolumn{3}{|c|}{$\%$ coverage by trees } & \multicolumn{4}{|l|}{10.9} \\
\hline
\end{tabular}

(Fig. 6). There was no rainfall data recorded beyond 1992 to date following the 1994 genocide. Rainfall is bi-modal with a long dry period in June-September and a short one in February, with December and
January also being relatively dry. The rainfall observed here is similar to that recorded previously for the central plateau agro-ecological zone (Delepierre 1982). Applying the unadjusted models of Whitehead 
Table 4 Woodlot area, estimates of potential tree transpiration $\left(E_{t p}\right)$ and extent of cover by Eucalyptus woodlots in southern Busoro subcatchment

\begin{tabular}{|c|c|c|c|c|c|}
\hline \multirow[t]{2}{*}{ Plot no. } & \multirow[t]{2}{*}{ Woodlot area $\left(\mathrm{m}^{2}\right)$} & \multicolumn{3}{|c|}{ Tree potential transpiration $\left(E_{t p}\right)$} & \multirow[t]{2}{*}{ Cover $(\%)$} \\
\hline & & $\left(\mathrm{g} \mathrm{d}^{-1}\right)$ & $\left(\mathrm{g} \mathrm{d}^{-1} \mathrm{~m}^{2}\right)$ & $\left(\mathrm{mm} \mathrm{d}^{-1}\right)$ & \\
\hline $35+37$ & 28,500 & $5.26 \mathrm{E}+07$ & 1847 & 1.85 & 100 \\
\hline 47 & 19,000 & $6.02 \mathrm{E}+07$ & 3168 & 3.17 & 100 \\
\hline 48 & 3700 & $1.59 \mathrm{E}+07$ & 4284 & 4.28 & 100 \\
\hline 49 & 38,000 & $2.16 \mathrm{E}+08$ & 5682 & 5.68 & 98 \\
\hline 50 & 154,000 & $5.44 \mathrm{E}+08$ & 3534 & 3.53 & 100 \\
\hline 51 & 30,000 & $1.10 \mathrm{E}+08$ & 3676 & 3.68 & 97 \\
\hline 52 & 74,000 & $2.44 \mathrm{E}+08$ & 3299 & 3.3 & 100 \\
\hline 53 & 3000 & $1.71 \mathrm{E}+07$ & 5684 & 5.68 & 100 \\
\hline 54 & 82,900 & $2.63 \mathrm{E}+08$ & 3177 & 3.18 & 100 \\
\hline 55 & 51,000 & $2.56 \mathrm{E}+08$ & 5015 & 5.02 & 100 \\
\hline 56 & 62,000 & $2.80 \mathrm{E}+08$ & 4509 & 4.51 & 100 \\
\hline 57 & 3000 & $1.93 \mathrm{E}+07$ & 6439 & 6.44 & 90 \\
\hline 58 & 3500 & $1.43 \mathrm{E}+07$ & 4100 & 4.1 & 100 \\
\hline 59 & 6500 & $1.45 \mathrm{E}+07$ & 2224 & 2.22 & 100 \\
\hline $58+59$ & 22,000 & $6.96 \mathrm{E}+07$ & 3162 & 3.16 & 100 \\
\hline Total & 581,100 & $2.18 \mathrm{E}+09$ & 3746 & 3.75 & 100 \\
\hline \multicolumn{2}{|c|}{ Total area catchment $\left(\mathrm{m}^{2}\right)$} & \multicolumn{4}{|l|}{$4,392,000$} \\
\hline \multicolumn{2}{|c|}{$\%$ coverage by trees } & \multicolumn{4}{|l|}{13.2} \\
\hline
\end{tabular}

\begin{tabular}{lcrlrl}
\hline Plot no. & Woodlot area $\left(\mathrm{m}^{2}\right)$ & \multicolumn{2}{l}{ Potential tree transpiration $\left(E_{t p}\right)$} & Cover (\%) \\
\cline { 3 - 5 } & & $\left(\mathrm{g} \mathrm{d}^{-1}\right)$ & $\left(\mathrm{g} \mathrm{d}^{-1} \mathrm{~m}^{-2}\right)$ & $\left(\mathrm{mm} \mathrm{d}^{-1}\right)$ & \\
\hline 1 & 101,000 & $280,116,110$ & 2773 & 2.77 & 100 \\
2 & 120,000 & $349,608,055$ & 2913 & 2.91 & 100 \\
3 & 50,000 & $66,989,693$ & 1340 & 1.34 & 100 \\
4 & 131,000 & $247,621,809$ & 1890 & 1.89 & 98 \\
5 & 155,000 & $394,592,172$ & 2546 & 2.55 & 100 \\
6 & 172,000 & $591,586,594$ & 3439 & 3.44 & 98 \\
7 & 90,000 & $298,106,349$ & 3312 & 3.31 & 100 \\
Total & 819,000 & $2,228,620,782$ & 2721 & 2.72 & 99 \\
\multicolumn{7}{l}{ Total catchment area: $4,717,000\left(\mathrm{~m}^{2}\right)$} & & & \\
\multicolumn{2}{l}{$\%$ coverage by trees: $17.4 \%$} & & & & \\
\hline
\end{tabular}

$-2 \mathrm{~mm} \mathrm{~d}^{-1}$ ). Since water outflow cannot exceed water inflow, this indicates that annual actual $E_{t}$ did not equal annual $E_{t p}$, likely due to drought stress in the drier months. Rainfall in the region may seem not to be enough to support a year-round actual tree transpiration of $3 \mathrm{~mm} \mathrm{~d}^{-1}$. Estimated $E_{t}$ was much larger than $P$ in the months of June, July, August and September and to a lesser extent in January (Table 7). To obtain a more accurate estimation of the actual $E_{t}$, both $E_{t}$ and $E_{u}$ were adjusted according to the assumed 15, 30 and
Table 5 Woodlot area, estimates of potential tree transpiration $\left(E_{t p}\right)$ and extent of cover by Eucalyptus woodlots in Butare catchment, southern Rwanda 
Table 6 Weighted average estimates of potential tree transpiration $\left(E_{t p}\right)$ for Eucalyptus woodlots in Busoro and Butare catchments in southern Rwanda

\begin{tabular}{|c|c|c|c|c|c|c|c|}
\hline \multirow[t]{2}{*}{ Catchment } & \multirow{2}{*}{$\begin{array}{l}\text { Catchment } \\
\text { area } \\
\left(\mathrm{m}^{2}\right)\end{array}$} & \multirow{2}{*}{$\begin{array}{l}\text { Total area } \\
\text { under trees } \\
\left(\mathrm{m}^{2}\right)\end{array}$} & \multirow{2}{*}{$\begin{array}{l}\% \text { Area } \\
\text { covered by } \\
\text { trees } \\
(\%)\end{array}$} & \multicolumn{3}{|c|}{ Tree transpiration } & \multirow{2}{*}{$\begin{array}{l}\text { Eucalypt } \\
\text { cover/woodlot } \\
(\%)\end{array}$} \\
\hline & & & & $\left(\mathrm{g} \mathrm{d}^{-1}\right)$ & $\left(\mathrm{g} \mathrm{d}^{-1} \mathrm{~m}^{2}\right)$ & $\left(\mathrm{Mm} \mathrm{d}^{-1}\right)$ & \\
\hline \multicolumn{8}{|l|}{ Busoro } \\
\hline Northern sub-catchment & $1,785,000$ & 193,000 & 10.8 & $4.36 \mathrm{E}+08$ & 2250 & 2.25 & 95 \\
\hline Southern sub-catchment & $4,392,000$ & 603,200 & 13.7 & $2.18 \mathrm{E}+09$ & 3612 & 3.61 & 100 \\
\hline Total & $6,177,000$ & 796,200 & 12.9 & $2.61 \mathrm{E}+09$ & 3371 & 3.37 & 99 \\
\hline Butare & $4,717,000$ & 819,000 & 17.4 & $2.26 \mathrm{E}+09$ & 2721 & 2.72 & 99 \\
\hline Weighted average & & & 14.6 & & 3037 & 3.04 & 99 \\
\hline
\end{tabular}

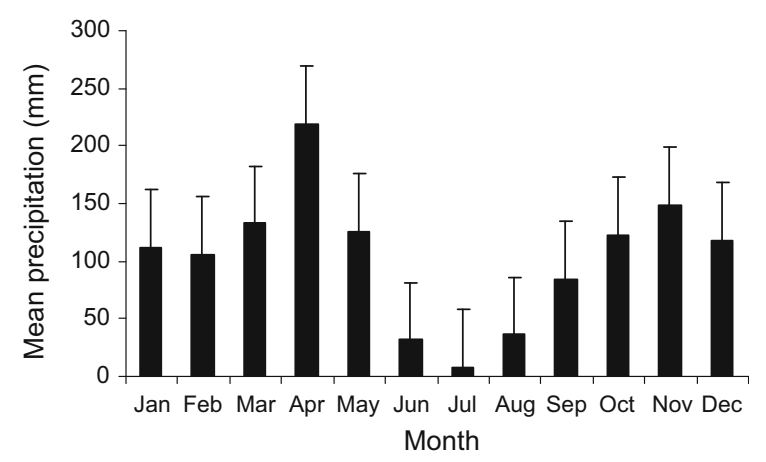

Fig. 6 Monthly mean precipitation of Butare area, southern Rwanda based on precipitation rates collected in Butare in 1971-1993

$50 \%$ reductions in the LAI during June-September. A reduction in LAI of $15 \%$ cut the yearly water balance by half from -84.0 to -39.3 . Decreasing LAI further resulted to a neutral to positive yearly water surpluses of 2 and $62.8 \mathrm{~mm} \mathrm{year}^{-1}$ for LAI reductions of 30 and $50 \%$ respectively (Table 8 ). Transpiration deficits during the drier months were assumed to be buffered by both the soil storage accumulated in wet months and stomatal closure as trees' physiological response to water deficits. Even in drier years, the differences in soil water storage are not likely to affect the water balance on an annual basis (Everson 2001).

\section{Discussion}

Eucalyptus woodlots in the study area mainly comprised of coppice stands of varying rotations of small young shoots with small DBH. Coppice shoot sizes are known to decline with the number of harvesting cycles in short rotation Eucalyptus plantations. Stand above ground biomass was observed to decrease as the number of cutting cycles increased (Zewdie 2008). Specific leaf area (SLA) obtained for E. saligna in this study $\left(16 \mathrm{~m}^{2} \mathrm{~kg}^{-1}\right)$ is only slightly higher than that obtained for E. grandis in Nyabeda, western Kenya (Radersma et al. 2006). This is not surprising since the two species are known to be morphologically similar (Burren 1996).

The estimated water use of Eucalyptus during the rainy season was generally less than that of key crops in the study area (Table 9). The average potential evapotranspiration $\left(E T_{c}\right)$ of Eucalyptus was reported to be $3.6 \mathrm{~mm} \mathrm{~d}^{-1}$ (1329 $\mathrm{mm} \mathrm{y}^{-1}$ ) (Gislain 2008). In comparison, the reference $E T, E T_{0}{ }^{1}$ is between 4 and $5 \mathrm{~mm} \mathrm{~d}^{-1}$ (i.e. 1460 and $1825 \mathrm{~mm} \mathrm{y}^{-1}$ ). Crops such as banana, cassava, beans and maize generally have a potential evapotranspiration $\left(E T_{c}\right)$ slightly greater than $5 \mathrm{~mm} \mathrm{~d}^{-1}$ in the mid-season (Gislain 2008).

There are few studies of Eucalyptus water use in Africa (Hailu et al. 2003). The water use observed in this study $\left(3 \mathrm{~mm} \mathrm{~d}^{-1}\right)$ is on the lower side of the range observed for Eucalyptus and for forests of other tree species. Water use ranged from 0.4 to $9.9 \mathrm{~mm} \mathrm{~d}^{-1}$ in Africa (Fritzsche et al. 2006; Radersma et al. 2006) and from 0.4 to $49.0 \mathrm{~mm} \mathrm{~d}^{-1}$ around the world (Morris et al. 2004). The small rate observed in the study area is attributed to the small tree size and LAI of

\footnotetext{
${ }^{1} E T_{0}$ is the reference evapotranspiration widely used in the field of irrigation as a reference surface for potential crop evapotranspiration. "The reference surface is a hypothetical grass reference crop with an assumed crop height of $0.12 \mathrm{~m}$, a fixed surface resistance of $70 \mathrm{~s} \mathrm{~m}^{-1}$ and an albedo of $0.23 . E T_{0}$ can be computed from meteorological data or estimated from pan evaporation (FAO guideline, Allen and Grime 1998).
} 
Table $7 E_{t p}$ in a monthly water balance $(W B)$ estimated for Eucalyptus woodlots in Busoro catchment, Butare, southern Rwanda based on Whitehead and Beadle (2004)

\begin{tabular}{lcccrr}
\hline Month & $P(\mathrm{~mm})^{*}$ & $E_{t p}(\mathrm{~mm})$ & $E_{i}(\mathrm{~mm})$ & $E_{u}(\mathrm{~mm})$ & $D+R(\mathrm{~mm})$ \\
\hline January & 112 & 93.0 & 11.2 & 9.3 & -1.5 \\
February & 106 & 84.0 & 10.6 & 8.4 & 3.0 \\
March & 132 & 93.0 & 13.2 & 9.3 & 16.5 \\
April & 219 & 90.0 & 21.9 & 9.0 & 98.1 \\
May & 126 & 93.0 & 12.6 & 9.3 & 11.1 \\
June & 32 & 90.0 & 3.2 & 9.0 & -70.2 \\
July & 8 & 93.0 & 0.8 & 9.3 & -95.1 \\
August & 36 & 93.0 & 3.6 & 9.3 & -69.9 \\
September & 84 & 90.0 & 8.4 & 9.0 & -23.4 \\
October & 123 & 93.0 & 12.3 & 9.3 & 8.4 \\
November & 149 & 90.0 & 14.9 & 9.0 & 35.1 \\
December & 118 & 93.0 & 11.8 & 9.3 & -84.0 \\
Total & 1245.0 & 1095.0 & 124.5 & 109.5 &
\end{tabular}

$P$ precipitation, $E_{t p}$ potential tree transpiration, $E_{i}$ interception losses, $E_{u}$ evaporation from the undergrowth and soil surface

* $P=E T+\Delta S+D+R$, where $P$ is precipitation, $E T$ is total evapotranspiration, $\Delta S$ is the change in total soil water storage, $D$ is drainage and $R$ is surface run-off, all in $\mathrm{mm} \mathrm{d}^{-1}$

Table 8 The adjusted potential tree transpiration through $L A$ reductions of 15,30 and $50 \%$ in dry seasons in a monthly water balance in Butare, southern Rwanda

\begin{tabular}{|c|c|c|c|c|c|c|c|c|c|c|c|}
\hline \multirow[t]{2}{*}{ Month } & \multirow[t]{2}{*}{$P(\mathrm{~mm}) *$} & \multicolumn{3}{|c|}{ Adj.Etp (mm) } & \multirow[t]{2}{*}{$E i(\mathrm{~mm})$} & \multicolumn{3}{|c|}{$\operatorname{Adj.Eu}(\mathrm{mm})$} & \multicolumn{3}{|c|}{ Surplus $(R+D)$} \\
\hline & & $L A_{85} \%$ & $L A_{70} \%$ & $L A_{50} \%$ & & $L A_{85} \%$ & $L A_{70} \%$ & $L A_{50} \%$ & $L A_{85} \%$ & $L A_{70} \%$ & $L A_{50} \%$ \\
\hline January & 112.0 & 91.6 & & & 11.2 & 9.2 & & & 0.0 & & \\
\hline February & 106.0 & 84.0 & 84.0 & 84.0 & 10.6 & 8.4 & 8.4 & 8.4 & 3.0 & 3.0 & 3.0 \\
\hline March & 132.0 & 93.0 & 93.0 & 93.0 & 13.2 & 9.3 & 9.3 & 9.3 & 16.5 & 16.5 & 16.5 \\
\hline April & 219.0 & 90.0 & 90.0 & 90.0 & 21.9 & 9.0 & 9.0 & 9.0 & 98.1 & 98.1 & 98.1 \\
\hline May & 126.0 & 93.0 & 93.0 & 93.0 & 12.6 & 9.3 & 9.3 & 9.3 & 11.1 & 11.1 & 11.1 \\
\hline June & 32.0 & 81.2 & 71.9 & 58.2 & 3.2 & 8.1 & 7.2 & 5.8 & -60.6 & -50.3 & -35.2 \\
\hline July & 8.0 & 82.1 & 72.7 & 58.8 & 0.8 & 8.2 & 7.3 & 5.9 & -83.2 & -72.8 & -57.5 \\
\hline August & 36.0 & 82.1 & 72.7 & 58.8 & 3.6 & 8.2 & 7.3 & 5.9 & -58.0 & -47.6 & -32.3 \\
\hline September & 84.0 & 81.2 & 71.9 & 58.2 & 8.4 & 8.1 & 7.2 & 5.8 & -13.8 & -3.5 & 11.6 \\
\hline October & 123.0 & 93.0 & 93.0 & 93.0 & 12.3 & 9.3 & 9.3 & 9.3 & 8.4 & 8.4 & 8.4 \\
\hline November & 149.0 & 90.0 & 90.0 & 90.0 & 14.9 & 9.0 & 9.0 & 9.0 & 35.1 & 35.1 & 35.1 \\
\hline December & 118.0 & 93.0 & 93.0 & 93.0 & 11.8 & 9.3 & 9.3 & 9.3 & 3.9 & 3.9 & 3.9 \\
\hline Total & 1245.0 & 1054.4 & 925.1 & 869.9 & 124.5 & 105.4 & 92.3 & 87.0 & -39.3 & 2.0 & 62.8 \\
\hline
\end{tabular}

$P$ precipitation, $A d j E_{t p}$ adjusted potential tree transpiration, $E_{i}$ interception losses, $A d j . E_{u}$ adjusted evaporation from under storey and soil surface, and $R$ and $D$ which add up to give water surplus

* $P=E T+\Delta S+D+R$, where $P$ is precipitation, $E T$ is total evapotranspiration, $\Delta S$ is the change in total soil water storage, $D$ is drainage and $R$ is surface run-off, all in $\mathrm{mm} \mathrm{d}^{-1}$

the frequently coppiced Eucalyptus. Tree water use is strongly related to heartwood area which in turn is directly dependent on tree DBH (Vertessy et al. 1995). E. saligna was observed to have a smaller LAI than other Eucalyptus and other tree species in Rwanda (Nsabimana et al. 2009). Eucalyptus woodlots generally have smaller LAI than other tree species (Nsabimana et al. 2009; Calder 1986) which may explain 
Table 9 Comparison of the potential evapotranspiration of Eucalyptus with $E T_{0}$ and the potential

evapotranspiration $\left(E T_{c}\right)$ of key crops in Rwanda

The $E T_{c}$ of the reference crops for the first and second year of growth are derived from a research conducted by the former Institut des Sciences Agronomiques du Rwanda, now Rwanda Agriculture Board (RAB) (Gislain 2008)

\begin{tabular}{|c|c|c|c|c|c|c|c|c|c|c|}
\hline \multirow[b]{3}{*}{ Month } & \multirow{3}{*}{$\begin{array}{l}{ }^{1} E T_{0} \\
(\mathrm{~mm})\end{array}$} & \multirow{2}{*}{\multicolumn{2}{|c|}{$\frac{\text { Banana }}{E T_{c}(\mathrm{~mm})}$}} & \multirow{2}{*}{\multicolumn{2}{|c|}{$\frac{\text { Cassava }}{E T_{c}(\mathrm{~mm})}$}} & \multirow{2}{*}{\multicolumn{2}{|c|}{$\frac{\text { Maize }}{E T_{c}(\mathrm{~mm})}$}} & \multirow{2}{*}{\multicolumn{2}{|c|}{$\frac{\text { Beans }}{E T_{c}(\mathrm{~mm})}$}} & \multirow{3}{*}{$\begin{array}{l}\text { Eucalyptus } \\
E T_{c}(\mathrm{~mm}) \\
\text { Pot. }\end{array}$} \\
\hline & & & & & & & & & & \\
\hline & & yr1 & yr2 & yr 1 & yr 2 & yr 1 & yr 2 & yr 1 & yr 2 & \\
\hline January & 149 & 78 & 155 & 124 & 171 & 0 & 0 & 47 & 0 & 114 \\
\hline February & 148 & 84 & 140 & 112 & 154 & 56 & 0 & 0 & 0 & 103 \\
\hline March & 155 & 130 & 171 & 109 & 140 & 124 & 0 & 0 & 0 & 116 \\
\hline April & 141 & 150 & 165 & 60 & 66 & 135 & 0 & 0 & 0 & 121 \\
\hline May & 130 & 155 & 171 & 0 & 47 & 149 & 53 & 0 & 0 & 115 \\
\hline June & 123 & 150 & 165 & 0 & 45 & 105 & 105 & 0 & 60 & 102 \\
\hline July & 130 & 155 & 171 & 0 & 47 & 0 & 140 & 0 & 155 & 103 \\
\hline August & 143 & 155 & 171 & 0 & 47 & 0 & 155 & 0 & 155 & 106 \\
\hline September & 147 & 150 & 165 & 0 & 45 & 0 & 60 & 0 & 0 & 107 \\
\hline October & 161 & 78 & 155 & 47 & 109 & 0 & 0 & 62 & 0 & 115 \\
\hline November & 141 & 75 & 150 & 90 & 165 & 0 & 0 & 171 & 0 & 114 \\
\hline December & 140 & 78 & 155 & 124 & 171 & 0 & 0 & 155 & 0 & 114 \\
\hline Total & 1708 & 1437 & 1932 & 665 & 1204 & 569 & 512 & 435 & 370 & 1329 \\
\hline
\end{tabular}

the average annual quantity of water evapotranspired per hectare. This concept was successfully applied by Wise et al. (2011) in comparing water use by indigenous and introduced forests.

Transpiration is strongly dependent on LAI (Benyon and Nambiar 2006) which declines during the dry seasons (Shi et al. 2012; Morris et al. 2004) as it depends on available water (White et al. 2010) and temperature (Gholz 1982). LAI of fast growing eucalypt forests is also known to be dynamic both seasonally and between years (Le Maire et al., 2011), especially in evergreen forests prone to seasonal droughts (Turner et al. 2008). Large structural changes of the canopy that occur over the rotation affect LAI, crown cover, leaf angle and SLA (Laclau et al. 2010). There is a strong linear relationship between tree LAI and mean daily water use for a wide range of Eucalyptus species grown under similar climatic conditions (Hatton et al. 1995). It was observed that, for each additional $100 \mathrm{~mm} \mathrm{y}^{-1}$ in rainfall, LAI increased 0.3 units and productivity increased $2.3 \mathrm{Mg} \mathrm{ha}^{-1}$ year $^{-1}$, resulting in an additional increment of 7.6 Mg ha ${ }^{-1}$ year $^{-1}$ per added unit of LAI (Ryan et al. 2010). E. saligna (Ares and Fownes 2000) and E. grandis (Kallarackal and Somen 1997) are known to exhibit stomatal closure in response to stronger atmospheric vapour pressure deficits to reduce the $E_{t p}$.

LAI during the mid- to late-dry seasons is reported to decline following water shortages in the soil, and is usually reported to be $40-50 \%$ smaller than its value during the wet- and early-dry seasons in Eucalyptus 
forests (Nouvellon et al. 2010). Reductions in the LAI were reported to be up to $50 \%$ even in moist tropical forests in Congo-Guinean forest (de Wasseige et al. 2003), in Mexico (Mass et al. 1995) and in Thailand (Tanaka et al. 2003). In this study, an assumed dry season reduction in LAI $\left(E_{t p}\right)$ of $15 \%$ was observed to lead to a deficit in catchment water balance but a further increase in the reduction $(30 \%)$ lead to a neutral catchment water balance where $P$-ET gave a sum of $R+D$ of about $2 \mathrm{~mm}$. A higher rate LAI $\left(E_{t p}\right)$ reduction which may be expected to reach a maximum of $50 \%$ would lead to a more positive surplus. To a lesser extent, stomatal closure during the dry season as the soil water declines may reduce tree transpiration further, thereby reducing water loss by trees (Wullschleger et al. 1998) and thus, leading to a closed catchment water balance. The effect of this on tree growth was assumed to be minimal or none since dry seasons are usually dormant periods for tree growth.

According to climate data from 1982 to 1993 collected from Butare and Nyakibanda meteorological stations in the study area, the area experiences annual dry seasons of up to 4 months during which mean monthly temperatures range $17.1-20.6{ }^{\circ} \mathrm{C}$. This agrees with the general temperature for the central plateau agro-ecological zone reported by Delepierre (1982) that the mean annual temperature is $19.5^{\circ} \mathrm{C}$, with mean annual maxima and minima of 25.7 and $13.3{ }^{\circ} \mathrm{C}$ respectively. The temperatures are most likely to have increased following global climate change in the region, as affected by land cover change. In Africa, the role of cover changes, both natural and human induced, in modifying regional climates is perhaps most marked (Xue 1997). A study on African climate concludes that additional stresses on water resources are expected regardless of the rainfall alterations which are not clearly defined currently (Hulme et al. 2001).

Considering plantation water use at catchment level, there is a general agreement in most of the findings that tree species produce less surface run off, ground water recharge and stream flow than shallow rooted vegetation such as crops, pastures and grasslands (Benyon et al. 2007). Crops have a transpiring leaf area for only part of the year (Robinson et al. 2006) and consequently, recharge under agro-ecosystems may be one to two orders of magnitude greater than under natural vegetation (Tennant and Hall 2001). This may be a result of the trees' capacity to improve soil physical properties due to the addition of large quantities of litterfall and root biomass (Schroth et al. 1995), root activity of trees, root induced soil biological activity and tree roots leaving macropores following their decomposition (Van Noordwijk 1991). Litterfall of 6-9 $\mathrm{Mg} \mathrm{ha}^{-1}$ year $^{-1}$ was reported in Eucalyptus plantations at canopy closure in a large range of tropical environments (Du Toit 2008). Likewise, large quantities of fine roots were reported in Eucalyptus plantations in the Congo with wide and deep soil volume exploration, which were thought to prevent water and nutrient losses by deep drainage and to contribute to the maximisation of resource uses (Laclau et al. 2003).

If well situated within a catchment, trees may improve instead of negatively affect catchment hydrology. Trees located close to rivers may affect stream flows more severely owing to their large size and more abundant leaves with greater leaf area (Dvorak 2012). Dvorak (2012) further observed that the severity of problems associated with water extraction are greater where plantations are large in size and cover most of the catchment area or in places with seasonally low rainfall. In this way, well planned agroforestry practice may provide an option of locating trees on sites where they can provide net hydrological benefits, such as controlling run off rates where this is a problem (Keenan et al. 2004). In our study, most woodlots were growing on the hillside, reasonably far from the River Nyiranda. Negligible impacts are expected in catchments in which plantations are established on sites which are hydrogeologically isolated from streams (O'Loughlin and Nambiar 2001).

The potential impact of land use change on catchment hydrology may depend on the type of native vegetation replaced by exotics and on the extent of the land area covered by the new species (Albaugh et al. 2013). Unfortunately, there are no records of the vegetation types that were replaced by Eucalyptus woodlots in the study area and the respective water use. Generally, indigenous vegetation was reported to have less annual evapotranspiration than exotics since they usually show shallow roots and are seasonally dormant (Albaugh et al. 2013).

The rate of water use by Eucalyptus trees depends on the amount of rainfall and soil water available (Dye et al. 2001) and more water is transpired when water is plenty and vice versa (White et al. 2010). Similarly, wetter catchments were observed to have greater water flow reductions in South Africa (Scott et al. 2000). 
With this fact, more water flow reductions may be expected in the northern and western Provinces of Rwanda where Eucalyptus populations are larger (Nduwamungu et al. 2008) and the two regions have higher elevation and higher average annual rainfall compared to the eastern and the southern Provinces (GoR 2011). However, Gush et al. (2002) cautioned that the results from one catchment cannot be extrapolated to other areas with confidence because of differences in local climates.

\section{Conclusion}

Short rotation eucalypt stands in the study area had small shoot sizes with DBH ranging from 2 to $36 \mathrm{~cm}$ due to frequent coppicing. Potential tree transpiration $\left(E_{t p}\right)$ for eucalypt woodlots ranged from 0.41 to $6.44 \mathrm{~mm} \mathrm{~d}^{-1}$ (mean $2.93 \mathrm{~mm} \mathrm{~d}^{-1}$ ) for the Busoro catchment and from 1.34 to $3.44 \mathrm{~mm} \mathrm{~d}^{-1}$ (mean $2.72 \mathrm{~mm} \mathrm{~d}^{-1}$ ) for the Butare catchment. The overall mean $E_{t p}$ for eucalypt woodlots in the study area was about $3 \mathrm{~mm} \mathrm{~d}^{-1}$, equivalent to $1095\left(\mathrm{~mm} \mathrm{year}^{-1}\right)$. It should be noted that this is a conservative estimate, based on the assumption that runoff and drainage only occurred when available water exceeded annual $E_{t p}$. Long term precipitation of the study site was $1245 \mathrm{~mm}$ year $^{-1}$ on average, which is $150 \mathrm{~mm}$ year $^{-1}$ greater than the observed potential tree transpiration. The observed surplus annual catchment water balance suggests that short rotation eucalypt woodlots may not negatively affect the hydrology. Small deficits observed during the driest months of June, July, August and September may be eliminated by physiological responses of trees through reducing LAI and to a lesser extent, stomatal closure. A sensitivity analysis on the variation of the $L A$ during the dry seasons resulted into $E_{t p}$ decreases. A possible maximum $50 \% L A$ reduction for example lead to a corresponding decrease of $32.8 \mathrm{~mm}$ in $E_{t p}$. Extra shortages if any may be evened out by soil storage, which can be recharged in the wetter months. The observed deficit in soil water during dry seasons is not expected to impact tree growth negatively since trees usually do not grow during the dry seasons. The moderate eucalypt water use rate observed in this study may be a function of the small size of trees and low stand density since less dense woodlots with smaller trees had much less potential transpiration. Managing the woodlots at short rotations (to produce small stems), plus increasing initial tree spacing, may contribute to the reduced catchment hydrology problems associated with eucalypt plantations. The observed water use rate of eucalypt woodlots was less than that of many annual crops in the study area and eucalypt trees in Africa and elsewhere in the world. In addition to biophysical water use efficiency, economic water use efficiency may be a useful option for water use comparisons among different production options.

Acknowledgments We kindly thank the Netherlands organization for international cooperation in higher education (NUFFIC) for funding this study through a joint project (NPT/ RWA/061) between Wageningen University and the University of Rwanda. Sincere thanks to Emmanuel Nsabimana from Rwanda Agriculture Board for assisting in field data collection.

Open Access This article is distributed under the terms of the Creative Commons Attribution 4.0 International License (http:// creativecommons.org/licenses/by/4.0/), which permits unrestricted use, distribution, and reproduction in any medium, provided you give appropriate credit to the original author(s) and the source, provide a link to the Creative Commons license, and indicate if changes were made.

\section{Appendix}

See Table 10.

Table 10 Number of sample plots/woodlot, tree species, number of stems, tree DBH and leaf area of woodlot trees in Busoro northern sub-catchment (NB), southern Rwanda

\begin{tabular}{|c|c|c|c|c|c|c|c|c|c|c|}
\hline \multirow[t]{2}{*}{ Wood-lot no. } & \multirow[t]{2}{*}{ Plot no. } & \multirow[t]{2}{*}{ Species } & \multicolumn{2}{|c|}{ No. of stems } & \multicolumn{3}{|c|}{ Tree DBH $(\mathrm{cm})$} & \multicolumn{3}{|c|}{ Tree leaf area $\left(\mathrm{m}^{2}\right)$} \\
\hline & & & $\left(\right.$ plot $\left.^{-1}\right)$ & $\left(\mathrm{ha}^{-1}\right)$ & Min & Max & $\mathrm{Av} \pm \mathrm{Std}$ & Min & Max & $\mathrm{Av} \pm \mathrm{Std}$ \\
\hline NB-1* & 1 & E. saligna & 83 & 450 & 5 & 36 & $17 \pm 6$ & 22 & 520 & $166 \pm 99$ \\
\hline NB-2 & 2 & E. tereticornis & 280 & 800 & 2 & 28 & $12 \pm 6$ & 8 & 267 & $80 \pm 56$ \\
\hline \multirow[t]{2}{*}{ NB-3 } & 3 & E. saligna & 8 & 250 & 2 & 6 & $3 \pm 2$ & 10 & 36 & $17 \pm 9$ \\
\hline & & E. tereticornis & 24 & 800 & 2 & 10 & $5 \pm 2$ & 7 & 52 & $19 \pm 10$ \\
\hline
\end{tabular}


Table 10 continued

\begin{tabular}{|c|c|c|c|c|c|c|c|c|c|c|}
\hline \multirow[t]{2}{*}{ Wood-lot no. } & \multirow[t]{2}{*}{ Plot no. } & \multirow[t]{2}{*}{ Species } & \multicolumn{2}{|c|}{ No. of stems } & \multicolumn{3}{|c|}{ Tree DBH $(\mathrm{cm})$} & \multicolumn{3}{|c|}{ Tree leaf area $\left(\mathrm{m}^{2}\right)$} \\
\hline & & & $\left(\right.$ plot $\left.^{-1}\right)$ & $\left(\mathrm{ha}^{-1}\right)$ & Min & $\operatorname{Max}$ & $\mathrm{Av} \pm \mathrm{Std}$ & Min & Max & $\mathrm{Av} \pm \mathrm{Std}$ \\
\hline & & E. maidenii & 10 & 350 & 2 & 11 & $6 \pm 4$ & 8 & 69 & $32 \pm 24$ \\
\hline NB-4 & 4 & E. tereticornis & 17 & 850 & 2 & 13 & $6 \pm 3$ & 7 & 74 & $28 \pm 20$ \\
\hline \multirow[t]{2}{*}{ NB-5 } & 5 & E. saligna & 62 & 3100 & 2 & 10 & $5 \pm 2$ & 10 & 69 & $26 \pm 12$ \\
\hline & & E. microcorys & 7 & 350 & 5 & 6 & $5 \pm 1$ & 19 & 28 & $22 \pm 3$ \\
\hline \multirow[t]{2}{*}{ NB-6 } & 6 & E. saligna & 29 & 1450 & 2 & 17 & $6 \pm 3$ & 8 & 164 & $33 \pm 30$ \\
\hline & & E. tereticornis & 10 & 500 & 4 & 12 & $7 \pm 2$ & 15 & 66 & $32 \pm 15$ \\
\hline NB-7 & 7 & E. tereticornis & 28 & 1400 & 3 & 5 & $3 \pm 1$ & 9 & 19 & $12 \pm 2$ \\
\hline \multirow[t]{3}{*}{ NB-8 } & 8 & E. saligna & 26 & 150 & 8 & 8 & $8 \pm 0$ & 49 & 49 & $49 \pm 0$ \\
\hline & & E. microcorys & 3 & $<50$ & 5 & 5 & $5 \pm 0$ & 22 & 22 & $22 \pm 0$ \\
\hline & & Other & 27 & 200 & 4 & 30 & $18 \pm 7$ & 16 & 346 & $157 \pm 81$ \\
\hline \multirow[t]{3}{*}{ NB-9 } & 9 & E. saligna & 13 & 650 & 2 & 9 & $5 \pm 2$ & 10 & 57 & $26 \pm 15$ \\
\hline & & E. microcorys & 1 & 50 & 3 & 3 & 3 & 12 & 12 & 12 \\
\hline & & Other & 7 & 350 & 12 & 23 & $18 \pm 4$ & 75 & 226 & $155 \pm 51$ \\
\hline NB-10 & 10 & Other & 14 & 700 & 8 & 25 & $19 \pm 5$ & 42 & 248 & $165 \pm 63$ \\
\hline NB-11 & 11 & E. saligna & 33 & 1000 & 2 & 10 & $5 \pm 2$ & 9 & 73 & $25 \pm 15$ \\
\hline NB-12 & 12 & E. tereticornis & 38 & 1150 & 3 & 12 & $6 \pm 3$ & 9 & 65 & $28 \pm 17$ \\
\hline \multirow[t]{5}{*}{ NB-13 } & $13-14$ & E. saligna & 39 & 950 & 2 & 11 & $5 \pm 2$ & 10 & 80 & $26 \pm 17$ \\
\hline & & E. tereticornis & 55 & 1350 & 2 & 8 & $4 \pm 2$ & 6 & 36 & $12 \pm 7$ \\
\hline & & E. citriodora & 5 & 100 & 2 & 9 & $6 \pm 3$ & 8 & 46 & $30 \pm 20$ \\
\hline & & E. maidenii & 1 & $<50$ & 7 & 7 & 7 & 35 & 35 & 35 \\
\hline & & Other & 13 & 300 & 2 & 7 & $3 \pm 2$ & 8 & 36 & $15 \pm 8$ \\
\hline NB-14 & 15 & E. tereticornis & 49 & 1000 & 2 & 8 & $4 \pm 2$ & 6 & 38 & $14 \pm 8$ \\
\hline NB-15 & 16 & E. tereticornis & 210 & 3500 & 2 & 19 & $5 \pm 4$ & 6 & 142 & $24 \pm 27$ \\
\hline \multirow[t]{3}{*}{ NB-16 } & 17 & E. tereticornis & 31 & 600 & 3 & 6 & $4 \pm 1$ & 9 & 24 & $13 \pm 4$ \\
\hline & & E. maidenii & 4 & 100 & 6 & 6 & $6 \pm 0$ & 25 & 25 & $25 \pm 0$ \\
\hline & & Other & 1 & $<50$ & 9 & 9 & 9 & 54 & 54 & 54 \\
\hline NB-17 & 18 & E. tereticornis & 37 & 2850 & 2 & 6 & $2 \pm 1$ & 6 & 24 & $9 \pm 3$ \\
\hline \multirow[t]{2}{*}{ NB-18 } & $19-20$ & E. teriticornis & 134 & 3350 & 1 & 8 & $2 \pm 1$ & 5 & 37 & $10 \pm 5$ \\
\hline & & E. maidenii & 2 & 50 & 3 & 10 & $6 \pm 5$ & 12 & 56 & $34 \pm 31$ \\
\hline \multirow[t]{3}{*}{ NB-19 } & $21-22$ & E. saligna & 3 & 50 & 8 & 12 & $10 \pm 2$ & 52 & 88 & $66 \pm 19$ \\
\hline & & E. teriticornis & 35 & 850 & 1 & 11 & $7 \pm 3$ & 5 & 64 & $33 \pm 17$ \\
\hline & & Other & 2 & 50 & 3 & 4 & $4 \pm 0$ & 14 & 15 & $14 \pm 1$ \\
\hline NB-20 & $23-24$ & E. saligna & 75 & 1850 & 2 & 15 & $7 \pm 3$ & 8 & 125 & $41 \pm 26$ \\
\hline NB-21 & 25 & E. teriticornis & 59 & 2950 & 2 & 5 & $2 \pm 1$ & 6 & 18 & $9 \pm 3$ \\
\hline \multirow[t]{2}{*}{ NB-22 } & $26-27$ & E. teriticornis & 29 & 700 & 2 & 28 & $2 \pm 1$ & 7 & 310 & $161 \pm 69$ \\
\hline & & E. camaldulencis & 35 & 850 & 4 & 36 & $17 \pm 7$ & 15 & 454 & $147 \pm 90$ \\
\hline \multirow[t]{2}{*}{ NB-23 } & $28-29$ & E. saligna & 64 & 1600 & 2 & 13 & $5 \pm 3$ & 8 & 101 & $27 \pm 21$ \\
\hline & & E. teriticornis & 33 & 800 & 2 & 11 & $5 \pm 3$ & 6 & 60 & $20 \pm 16$ \\
\hline \multirow[t]{3}{*}{ NB-24 } & 30 & E. saligna & 11 & 550 & 2 & 4 & $2 \pm 1$ & 10 & 20 & $12 \pm 3$ \\
\hline & & E. teriticornis & 65 & 3250 & 1 & 5 & $2 \pm 1$ & 5 & 20 & $8 \pm 3$ \\
\hline & & E. microcorys & 2 & 100 & 2 & 2 & $2 \pm 1$ & 7 & 10 & $8 \pm 2$ \\
\hline \multirow[t]{2}{*}{ NB-25 } & $31-36$ & E. saligna & 103 & 850 & 1 & 10 & $4 \pm 2$ & 6 & 69 & $19 \pm 14$ \\
\hline & & E. teriticornis & 281 & 2350 & 1 & 19 & $3 \pm 2$ & 5 & 142 & $15 \pm 16$ \\
\hline
\end{tabular}


Table 10 continued

\begin{tabular}{|c|c|c|c|c|c|c|c|c|c|c|}
\hline \multirow[t]{2}{*}{ Wood-lot no. } & \multirow[t]{2}{*}{ Plot no. } & \multirow[t]{2}{*}{ Species } & \multicolumn{2}{|c|}{ No. of stems } & \multicolumn{3}{|c|}{ Tree DBH $(\mathrm{cm})$} & \multicolumn{3}{|c|}{ Tree leaf area $\left(\mathrm{m}^{2}\right)$} \\
\hline & & & $\left(\right.$ plot $\left.^{-1}\right)$ & $\left(\mathrm{ha}^{-1}\right)$ & Min & Max & $\mathrm{Av} \pm \mathrm{Std}$ & Min & Max & $\mathrm{Av} \pm \mathrm{Std}$ \\
\hline & & E. microcorys & 2 & $<50$ & 2 & 2 & $2 \pm 1$ & 7 & 10 & $8 \pm 2$ \\
\hline & & Other & 9 & 50 & 5 & 14 & $8 \pm 4$ & 22 & 100 & $46 \pm 37$ \\
\hline \multirow[t]{4}{*}{ NB-26 } & $35+37$ & E. saligna & 47 & 1150 & 1 & 8 & $4 \pm 2$ & 6 & 49 & $18 \pm 10$ \\
\hline & & E. teriticornis & 68 & 1700 & 1 & 8 & $3 \pm 2$ & 5 & 34 & $11 \pm 7$ \\
\hline & & E. microcorys & 18 & 450 & 2 & 5 & $3 \pm 1$ & 7 & 24 & $13 \pm 5$ \\
\hline & & Other & 1 & $<50$ & 20 & 20 & 20 & 176 & 176 & 176 \\
\hline \multirow[t]{4}{*}{ NB-27 } & 38 & E. saligna & 31 & 1550 & 1 & 17 & $7 \pm 4$ & 6 & 158 & $46 \pm 36$ \\
\hline & & E. teriticornis & 63 & 3150 & 1 & 12 & $5 \pm 3$ & 5 & 64 & $21 \pm 14$ \\
\hline & & E. maidenii & 2 & 100 & 7 & 17 & $12 \pm 7$ & 32 & 130 & $81 \pm 69$ \\
\hline & & Other & 25 & 1250 & 1 & 4 & $2 \pm 1$ & 6 & 19 & $10 \pm 4$ \\
\hline NB-28 & 39 & E. teriticornis & 75 & 3750 & 2 & 9 & $4 \pm 3$ & 6 & 41 & $20 \pm 15$ \\
\hline \multirow[t]{2}{*}{ NB-29 } & 40 & E. teriticornis & 79 & 3950 & 1 & 7 & $3 \pm 1$ & 5 & 27 & $10 \pm 5$ \\
\hline & & Other & 10 & 500 & 3 & 15 & $8 \pm 3$ & 12 & 107 & $50 \pm 28$ \\
\hline \multirow[t]{3}{*}{ NB-30 } & 41 & E. saligna & 101 & 5000 & 1 & 7 & $3 \pm 1$ & 6 & 36 & $14 \pm 7$ \\
\hline & & E. teriticornis & 48 & 2400 & 1 & 10 & $3 \pm 2$ & 5 & 48 & $13 \pm 8$ \\
\hline & & Other & 3 & 150 & 2 & 3 & $3 \pm 1$ & 10 & 13 & $11 \pm 2$ \\
\hline \multirow[t]{2}{*}{ NB-31 } & 42 & E. saligna & 3 & 150 & 1 & 2 & $2 \pm 1$ & 6 & 11 & $9 \pm 2$ \\
\hline & & E. teriticornis & 89 & 4450 & 1 & 6 & $2 \pm 1$ & 5 & 24 & $8 \pm 4$ \\
\hline NB-32 & 43 & E. teriticornis & 153 & 7600 & 1 & 5 & $2 \pm 1$ & 5 & 20 & $8 \pm 3$ \\
\hline \multirow[t]{2}{*}{ NB-33 } & $42-43$ & E. saligna & 3 & 50 & 1 & 2 & $2 \pm 1$ & 6 & 11 & $9 \pm 2$ \\
\hline & & E. teriticornis & 242 & 6000 & 1 & 6 & $2 \pm 1$ & 5 & 24 & $8 \pm 3$ \\
\hline NB-34 & 44 & E. teriticornis & 169 & 8400 & 1 & 6 & $2 \pm 1$ & 5 & 22 & $9 \pm 4$ \\
\hline \multirow[t]{4}{*}{ NB-35 } & 45 & E. saligna & 63 & 3150 & 1 & 16 & $3 \pm 2$ & 6 & 136 & $18 \pm 19$ \\
\hline & & E. teriticornis & 26 & 1300 & 1 & 7 & $3 \pm 2$ & 5 & 33 & $13 \pm 8$ \\
\hline & & E. maidenii & 3 & 150 & 5 & 7 & $6 \pm 1$ & 24 & 34 & $29 \pm 5$ \\
\hline & & Other & 7 & 350 & 2 & 15 & $6 \pm 4$ & 9 & 106 & $35 \pm 33$ \\
\hline NB-36 & 46 & Other & 90 & 300 & 20 & 25 & $22 \pm 2$ & 176 & 253 & $211 \pm 38$ \\
\hline
\end{tabular}

* Northern Busoro sub-catchment

\section{References}

Albaugh JM, Dye PJ, King JS (2013) Eucalyptus and water use in South Africa. A review article. Hindawi Publishing Corporation. Int J For Res, 2013: 11, Article ID 852540. doi: $10.1155 / 2013 / 852540$

Allen SJ, Grime VL (1998) Measurements of transpiration from savannah shrubs using sap flow gauges. Agric For Meteorol 75:2341

Ares A, Fownes HJ (2000) Productivity, nutrient and water use by Eucalyptus saligna and Toona ciliata in Hawaii. For Ecol Manage 129:227-236

Bayabil HK, Tilahun SA, Collick AS, Steenhuis TS (2010) Are runoff processes ecologically or topographically driven in the Ethiopian Highlands? The case of the Maybar. Ecohydrology 3:457-466

Benyon R, Nambiar S (2006) Forests and water. Science information forest and land use policy in southern Australia. In
International conference on forest and water in a changing environment, Beijing, China, August 8-10, 2006

Benyon R, England J, Eastham J, Polglase P, White D (2007) Tree water use in forestry compared to other dry-land agricultural crops in the Victorian context. Report prepared for the Department of Primary Industries Victoria to promote scientific knowledge in this area. Ensis Technical Report No. 159

Berbigier P, Bonnefond JM, Loustau D, Ferreira MI, David JS, Perreira JS (1996) Transpiration of a 64-year-old maritime pine stand in Portugal. 2. Evapotranspiration and canopy stomatal conductance measured by an eddy covariance technique. Oecol 107:43-52

Boland DJ, Brooker MIH, Chippendale GM, Hall N, Hyland BPM, Johnson RD (2006) Forest trees of Australia. Melbourne, CSIRO

Bouvet JM (1998) Les plantations d'Eucalyptus. Evolutions récentes et perspectives. Internal Note. CIRAD-Forêt, Montpellier, p 35 
Brockerhoff EG, Jactel H, Parrota JA, Ferraz SFB (2013) Role of eucalypt and other planted forests in biodiversity conservation and the provision of biodiversity-related ecosystem services. For Ecol Manag 301:43-50

Burren C (1996) Les Eucalyptus au Rwanda: Analyse de 60ans d'expérience avec référence particulière à l'arboretum de Ruhande. Intercoopération, Bern, Suisse, ISAR-Ruhande

Calder IR (1986) Water use of Eucalyptus - a review with special reference to South India. Agric Water Manag 11:333-342

Callister AN, Adams MA (2006) Water stress impacts on respiratory rate, efficiency and substrates, in growing and mature foliage of Eucalyptus spp. Planta 224:680-691

Chamshama SAO (2011) Forest plantations and woodlots in eastern and north-eastern African countries-a regional overview. Africa Forest Forum Working Paper Series Volume I No. 13. A platform for stakeholders in African forestry. African forestry. African Forest Forum

Davidson J (1993) Ecological aspects of eucalypt plantations. In: White K, Ball J and Kashio M (eds) Proceedings of Regional expert consultation on Eucalyptus held from 4 to 8 October, 1993. Vol I. FAO Regional Office for Asia and the Pacific, Bangkok, Thailand, pp 38-79. http://www.fao. org/docrep/005/ac/777e.ac.777e06.html. Accessed on 15 Aug 2013

De Wasseige C, Bastin D, Defourny P (2003) Seasonal variation of tropical forest leaf area index based on field measurements in Central African Republic. Agric For Meteorol 119:181-194

Delepièrre G (1982) Les régions agro-climatiques en relation avec l'intensité de l'erosion du Sol. Bull Agric Rwanda 2:87-95

Dessie D, Erkossa T (2011) Eucalyptus in East Africa: socioeconomic and environmental issues. Planted Forests and Trees Working Papers. FAO Working Paper No. FP46/E

Diao J, Lei X, Hong L, Rong J, Shi Q (2010) Single leaf area estimation models based on leaf weight of Eucalyptus in southern China. J For Res 21:73-76

Du Toit B (2008) Effects of site management on growth, biomass partitioning and light use efficiency in a young stand of Eucalyptus grandis in South Africa. For Ecol Manage 255:2324-2336

Dunin FX, Greenwood EAN (1986) Evaluation of the ventilated chamber for measuring evaporation from forest. Hydrol Process 1:47-62

Dvorak WS (2012) Water use in plantations of Eucalyptus and pines: a discussion paper from a tree breeding perspective. Int For Rev 14(1):2012

Dye PJ (2013) A review of changing perspectives on Eucalyptus water-use in South Africa. For Ecol Manag 301:51-57

Dye PJ, Versfeld D (2007) Managing the hydrological impacts of South African plantations: an overview. For Ecol Manag 251:121-128

Dye P, Vilakazi P, Gush M, Ndlela R, Royappen M (2001) Investigation of the feasibility of using trunk growth increments to estimate water use of Eucalyptus grandis and Pinus patula plantations. WRC Report 809/1/01, Water Research Commission, Pretoria, South Africa

Everson CS (2001) The water balance of a first order catchment in the montane grasslands of South Africa. J Hydrol 241:110-123
FAO (1979) Eucalyptus for planting. FAO forestry and forest products study No.11. FAO, Rome

FAO (2000) The global outlook for future wood supply from forest plantations by C. Brown. Working paper GFPOS/ WP/O3, Rome

Ferraz SFB, Lima WP, Rodrigues CB (2013) Managing forest plantations for water conservation. For Ecol Manag 301:58-66

Fritzsche F, Abate A, Fetene M, Beck E, Weise S, Guggenberger G (2006) Soil-plant hydrology of indigenous and exotic trees in an Ethiopian montane forest. Tree Physiol 6:1043-1054

Gahigana I (2006) No more Eucalyptus trees, says Official. The New Times, Kigali

Gholz HL (1982) Environmental limits on above ground net primary productivity, leaf area and biomass in vegetation zones of the Pacific. North West Ecol 63:467-481

Gislain NT (2008) Irrigation water requirement of prioritized crops in Nyagatare district. Institut des Sciences Agronomiques du Rwanda (ISAR). Rapport Annuel, Gestion des Sols et des Eaux

Government of Rwanda (GoR) (2011) Water resources management sub-sector strategic plan (2011-2015). Ministry of Natural Resources, Kigali

Gush MB, Scott DF, Jewitt GPW (2002) Estimation of stream flow reductions resulting from commercial afforestation in South Africa. WRC Report TT 173/02, Water Research Commission, Pretoria, South Africa

Hailu Z, Sieghardt M, Schume H, Ottner F, Glatzel G, Assefa B, Hailu TT (2003) Impact of Eucalyptus globulus and Eucalyptus camaldulensis small scale plantations on chemical and physical soil properties and on soil hydrology parameter in the highland of Ethiopia. A comparison with other land use systems. Final project report

Hall RIL, Calder IR, Rosier PTW (1992) Measurements and modeling of interception loss from a Eucalyptus plantation in southern India. In: Calder IR, Hall RL and Adlard PG (eds) Growth and water use of forest plantations. Wiley, Chichester, pp 270-289

Hatton TJ, Moore SJ, Reece PH (1995) Estimating stand transpiration in a Eucalyptus populnea woodland with the heat pulse method: measurement errors and sampling strategies. Tree Physiol 15:219-227

Hood S (2002) Rural water use efficiency-real water use efficiency and the opportunities. In: A paper read at 11th cotton conference of the Australian Cotton Growers Research Association, 13-15 August 2002 at Brisbane Convention and Exhibition Centre, Brisbane, Queensland, Australia

Hulme M, Doherty R, Ngara T, New M, Lister D (2001) African climate change: 1900-2100. Clim Res 17:145-168

Iglesias-Trabado G, Wilstermann D (2008) Eucalyptus Universalis. Global cultivated Eucalypt forest map 2008. Version 1.0.1. www.git-forestry.com. Accessed on $10 \mathrm{Mar}$ 2014

Jobbágy E, Baldi G, Nosetto M (2012) Tree plantation in South America and the water cycle: impacts and emergent opportunities. In: Schlichter T, Montes L (eds) Forests in development: a vital balance. Springer, Berlin, pp 53-63

Kaboggoza J (2011) Forest plantations and woodlots in Uganda. Africa Forest Forum Working Paper Series Volume I No. 
13. A platform for stakeholders in African forestry. African forestry. African Forest Forum

Kallarackal J, Somen CK (1997) An ecophysiological evaluation of the suitability of Eucalyptus grandis for planting in the tropics. For Ecol Manag 95:53-61

Keenan RJ, Parsons M, O'Loughlin E, Gerrand A, Beavis S, Gunawardana D, Gavran M, Bugg A (2004) Plantations and Water: a review. Report prepared for the Forest \& Wood Products Research \& Development Corporation, Bureau of Rural Sciences, Canberra, Australia, p 88

Laclau JP, da Silva EA, Lambias GR, Bemoux M, Maire G, Stape JL, Bouillet JP, Gonçalves GLM, Jourdan C, Nouvellon Y (2003) Dynamics of soil exploration by fine roots down to a depth of $10 \mathrm{~cm}$ throughout the entire rotation in Eucalyptus grandis plantation. Front Plant Sci 4:1-12

Laclau JP, Ranger J, de Moraes Gonçalves JLM, Maquere V, Krusche AV, M'Bou AT (2010) Biogeochemical cycles of nutrients in tropical Eucalyptus plantations: main features shown by intensive monitoring in Congo and Brazil. For Ecol Manag 259:1771-1785

Ladiges PY (1974) Variation in drought tolerance in Eucalyptus viminalis Labill. Aus J Bot 22:489-500

Lane PNJ, Morris J, Zhang N, Zhou G, Zhou G, Xu D (2004) Water balance of tropical eucalypt plantations in southeastern China. Agric For Meteorol 124:253-267

Le Maire G, Marsden C, Verhoef W, Ponzoni FJ, Seen DL, Begue A, Stape-L Nouvellon Y (2011) Leaf area index estimation with MODIS reflectance time series and model inversion during full rotations of Eucalyptus plantations. Rem Sens Environ 115:586-599

Lemenih M (2004) Effects of land use change on soil quality and native flora degradation and restoration in the highlands of Ethiopia. PhD Dissertation. ISSN 1401-6230, ISBN 91-576-6540-0, Swedish University of Agricultural Sciences, Department of Forest Soils, Uppsala

Mass JM, Vose JM, Swank WT, Martineez-Yrizar A (1995) Seasonal changes of leaf area index in a tropical deciduous forest in Mexico. For Ecol Manag 74:171-180

Morris J, Zhang NN, Yang ZJ, Collopy J, Xu DP (2004) Water use by fast growing Eucalyptus urophylla plantations in southern China. Tree Physiol 24:1035-1044

Ndayambaje JD, Heijman WJM, Mohren GMJ (2012) Household determinants of tree planting on farms in rural Rwanda. Small Scale For 11:477-508

Nduwamungu J (2011) Forest plantations and woodlots in Rwanda. African Forest Forum Working Paper Series Volume I No. 13. A platform for stakeholders in African forestry. African forestry. African Forest Forum

Nduwamungu J, Munyanziza E, Mukuralinda A, Ndayambaje JD, Gapusi J Ntirugulirwa B, Mutaganda A, Bambe JC, Gakwerere NE, Bizeye B, Ndizeye G, Ntabana D (2008) Inventaire des resources ligneuses du Rwanda. Rapport final Vol. II. Institut des Sciences Agronomiques du Rwanda, Butare, Rwanda

Nouvellon Y, Laclau J-P, Epron D, Kinana A, Mabiala A, Roupsard O, Bonnefond J-M, Le Maire G, Marsden C, Bontemps J-D, Saint Andre L (2010) Within-stand and seasonal variations of specific leaf area in a clonal Eucalyptus plantation in the Republic of Congo. For Ecol Manag 259:1796-1807
Nsabimana D, Klemedtson L, Kaplin DA, Wallin G (2009) Soil $\mathrm{CO}_{2}$ flux in six monospecific forest plantations in Southern Rwanda. Soil Biol Biochem 41:396-402

O'Loughlin E, Nambiar EKS (2001) Plantations, farm forestry and water. RIRDC/LWA/FWPRDC Publication No. 01/137. Canberra, Australia

Pook EW (1855) Canopy dynamics of Eucalyptus maculate Hook. III. Effects of drought. Aus J Bot 33:65-79

Radersma S, Ong CK, Coe R (2006) Water use of tree lines: importance of leaf area and micrometeorology in sub-humid Kenya. Agrofor Syst 66:179-189

Roberts JM, Rosier PTW, Srinivasa MKV (1992) Physiological studies in young Eucalyptus stands in southern India. In: Calder IR, Hall RL and Adlard PG (eds) Growth and water use of forest plantations. Wiley, Chichester, pp 226-243

Robinson N, Harper RJ, Smetten KRJ (2006) Soil water depletion by Eucalyptus spp. Integrated into dryland agricultural systems. Plant Soil 286:141-151

Rutter AJ (1968) Water consumption by forests. In: Koslowski TT (ed) Water deficits and plant growth. vol II. Plant water consumption and response. Academic Press, New York, pp 23-84

Ryan MG, Stape JL, Binkley D, Fonseca S, Loos RA, Takahashi EN, Silva CR, Silva SR, Hakamada RE, Ferreira JM, Lima AMN, Gava JL, Leite FP, Andrade HB, Alves JM, Silva GGC (2010) Factors controlling Eucalyptus productivity: how water availability and stand structure alter production and carbon allocation. For Ecol Manag 259:1695-1703

Schroth G, Kolbe D, Pity B, Zec W (1995) Searching for criteria for the selection of efficient tree species for fallow improvement, with the special reference to carbon and nitrogen. Fertil Res 42:297-314

Scott DF, Prinsloo FW, Moses G, Mehlomakulu M, Simmers ADA (2000) A re-analysis of the South African catchment afforestation experimental data”, WRC Report 810/1/00. Water Research Commission, Pretoria

Shi Z, Xu D, Yang X, Jia Z, Guo H, Zhang N (2012) Ecohydrological impacts of eucalypt plantations: a review. J Food Agric Environ 10:1419-1426

Tanaka K, Takizawa H, Tanaka N, Kosaka E, Yoshifuj N, Tantasirin C, Piman S, Suzuki M, Tangtham N (2003) Transpiration peak over a hill evergreen forest in southern Thailand in the late dry season: assessing the seasonal changes in evpotranspiration using a multi-layer model. J Geophys Res 108(D17):4533. doi:10.1029/2002JD003028

Tennant D, Hall D (2001) Improving water use of annual crops and pasture-limitations and opportunities in Western Australia. Aust J Agric Res 52:171-181

Turnbull JW (1999) Eucalyptus plantations. New For 17:37-52

Turner NC, Schulze E-D, Nicolle D, Schumacher J, Kuhlmann I (2008) Annual rainfall does not directly determine the carbon isotope ratio of leaves of Eucalyptus species. Physiol Plant 132:440-445

Van Noordwijk M (1991) Rooting depth in cropping systems in the humid tropics in relation to nutrient use efficiency. Institute for Soil fertility, Haren

Vertessy RA, Benyon RG, O'Sullivan SK, Gribben PR (1995) Relationships between stem diamenter and sapwood area, leaf area and transpiration in a young mountain ash forest. Tree Physiol 15:559-567 
White DA, Battaglia M, Mendham DS, Crombie DS, Kinal J, McGrath FJ (2010) Observed and modelled leaf area index in Eucalyptus globulus plantations: tests of optimality and equilibrium hypothesis. Tree Physiol 30:831-844

Whitehead D, Beadle CL (2004) Physiological regulation of productivity and water use in Eucalyptus: a review. For Ecol Manag 193:113-140

Wise RM, Dye PJ, Gush MB (2011) A comparison of the biophysical and economic water-use efficiencies of indigenous and introduced forests in South Africa. For Ecol Manag 262:906-915
Wullschleger SD, Meinzer FC, Vertessy RA (1998) A review of whole-plant water use studies in trees. Tree Physiol 18:499-512

Xue Y (1997) Biosphere feedback on regional climate in tropical north Africa. QJR Meteorol Soc 123:1483-1515

Zewdie M (2008) Temporal changes of biomass production, soil properties and ground flora in Eucalyptus globulus plantations in the Central Highlands of Ethiopia. Doctoral thesis Swedish University of Agricultural Sciences, Uppsala 